НАУКИ О ЗЕМЛЕ

"НАУКА. ИННОВАЦИИ. ТЕХНОЛОГИИ", №4, 2019

25.00 .30

МЕТЕОРОЛОГИЯ, КЛИМАТОЛОГИЯ, АГРОМЕТЕОРОЛОГИЯ

УДК 551.509.616/551.509.617

Ватиашвили M.P. Институт генетики Тбилисского Государственного университета им. И. Джавахишвили.

г. Тбилиси, Грузия. kbloto@bk.ru

\title{
МЕТОДЫ РАЙОНИРОВАНИЯ, КЛАССИФИКАЦИИ ПОЛЕЙ ОБЛАЧНОСТИ И СИНОПТИЧЕСКИХ ПРОЦЕССОВ КАВКАЗА И ПРИЛЕГАЮЩИХ ТЕРРИТОРИЙ ПО ДАННЫМ СНИМКОВ ИСЗ
}

Введение: $\quad$ по данным снимков с искусственных спутников Земли на Кавказе и прилегающих территориях проводится совершенствование метода классификации полей облаков и облачных систем. В качестве количественного показателя их макроструктурных особенностей привлекались номера типов (баллов) облачности, которые легли в основу дальнейшего совершенствования существующих методов классификации полей облачности и синоптических процессов, методов районирования, краткосрочного диагноза и прогноза эволюции полей облачности и осадков.

Задача совершенствования

методов: районирования включала в себя оценку определения климатической повторяемости существования тех или иных типов (баллов) облачности снимков ИСЗ с учетом опасных явлений погоды и объединения на этой основе идентичных участков сетки исследуемого региона; классификации синоптических процессов заключалась в оптимальном распределении элементов выборки по минимальному числу классов, которые определялись в процессе решения самой задачи классификации. Совершенствование полуавтоматизированного прогноза классификации синоптических процессов заключалось в разработке метода прогноза эволюции полей облачности над Кавказом с заблаговременностью 24 ч.

Материалы и методы исследований:

привлекались снимки с искусственных спутников Земли, синоптические карты погоды, справочники, научные монографии, атлас облаков, физико-статистические методы оценки характеристик полей облаков и облачных систем.

Результаты исследований

и их обсуждение: рассчитаны вероятности формирования общей облачности и облачности различных типов (баллов); построены карты вероятности формирования общей облачности с шагом $20 \%$ и отдельных типов облачности с шагом $10 \%$ и выявлены районы их интенсивного развития; усовершенствованы существующие методы классификации эволюции полей облаков и облачных систем, районирования и классификации синоптических процессов Кавказа и прилегающих территорий; разработан краткосрочный прогноз полей облаков и облачных систем и количества осадков с заблаговременностью 24 ч.

Выводы: $\quad$ многие из вышеперечисленных задач практически решены в работах автора. Они успешно применялись и применяются в прогностических организациях и противоградовых службах исследуемого региона.

Ключевые слова: искусственные спутники Земли, поля облаков и облачных систем, районирование, классисикация синоптических процессов. 
Vatiashvili M.R.

Introduction

The Institute of Genetics of Tbilisi State University named after I. Dzhavakhishvili, Tbilisi, Georgia. kbloto@bk.ru

\section{The Methods of Geographical Demarcation, Cloudiness Fields Classification and Synoptical Processes of the Caucasus As well as Adjacent Territories According to the Data of Artificial Earth Satellites (Aes) Images}

according to the data of artificial Earth satellites images the current method of cloud fields and cloud systems (CFCS) classification is being improved. As a quantitative indicator of their macrostructure peculiarities the numbers of cloudiness types (cloud amount), which are underlain into further improvement of the current methods of cloudiness fields and synoptical processes, methods of geographical demarcation, short-run diagnosis and the forecast of evolution of cloudiness and precipitation fields, have been applied.

The task of the current methods improvement:

Materials and research methods:

Research results and discussions:

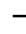

$-$

Conclusions:

Key words: of geographical demarcation included estimating the determination of climatic reproductibility of existence of these or those cloudiness types (cloud amount) accounting dangerous weather phenomena and combining on this basis identical sections of the chart of the region under study;

of synoptical processes classification consisted in the optimal distribution of sample units in the minimum number of classes which were determined in the process of solving the classification task.

The improvement of the semi-automated forecast of synoptical processes classification lay in the development of method of forecasting cloudiness fields evolution over the Caucasus prior to 24 hours.

the images of artificial Earth satellites, synoptic maps, reference books, scientific monographs, the Clouds Altlas, physical and statical methods of evaluation of cloud fields and cloud systems characteristics were applied.

the probabilities of forming general cloudiness and cloudiness of different types (cloud amount) have been calculated;

the charts of probable forming of general cloudiness with the range of $20 \%$ and particular cloudiness types with the range of $10 \%$ have been made and the districts of their intensive development have been identified;

the current methods of classification of cloud fields and cloud systems evolution, geographical demarcation and classification of the synoptical processes of the Caucasus and adjacent territories have been improved;

short-run forecast of cloud fields and cloud systems as well as precipitations amount prior to 24 hours has been developed.

many of the tasks mentioned above have been practically solved in author's works. They have been successfully applied in forecasting institutions and antihail protection services of the region under study.

artificial Earth satellites, cloud and cloud systems fields, geographical demarcation, synoptical processes classification 


\section{Введение}

При анализе структуры, динамики развития полей облаков и облачных систем (ПООС), процессов зарождения и эволюции гидрометеоров наблюдаем явления различных синоптических масштабов [13, 16, 17, 19,20, 24, 25].

Микромасштабные процессы в ПООС характеризуются размерами жидких и твердых гидрометеоров в диапазоне значений 0,02 мкм 5 см и продолжительностью их существования в диапазоне значений от нескольких секунд до десятков минут.

Мезомасштабные процессы в ПООС характеризуются горизонтальной протяженностью в диапазоне значений от 2 до 100 км и продолжительностью их существования в диапазоне от нескольких часов до 3 суток.

Макромасштабные процессы в ПООС характеризуются горизонтальной протяженностью от 1 тыс. до 10 тыс. км и продолжительностью их существования от 4 до 13 суток, составляя в среднем 5-7 суток.

В процессах различного масштаба формируются:

циклоны, антициклоны и безградиентные поля относительно пониженного и повышенного давления; теплые фронты, холодные основные и вторичные фронты, фронты окклюзии по типу холодного и теплого фронтов и волновые возмушения. Прохождение их через различные регионы мира сопровождается обложными осадками, интенсивными ливнями, градобитиями и шквалами различной силы со значительным ущербом народного хозяйства, исчисляемыми сотнями млн. долларов $[1,3,8,11,13,17,20,23]$.

К такому региону относится и регион Центрального Кавказа с прилегающими территориями, где с 1967 г. проводятся производственные работы по противоградовой защите (ПГЗ) сельскохозяйственных культур $(\mathrm{c} / \mathrm{x})$ от градобитий с применением противоградовых снарядов, ракет и различных методов воздействия на них $[1,2,7-9,10,14,23]$. Несколько позже в исследуемых районах этого региона начались и производственные работы по искусственному увеличению осадков (ИУО) из конвективных облаков, с применением наземной противоградовой и самолетной технологии засева $[22,30]$.

На географических картах Кавказ и прилегающие территории занимают пространство от $35^{\circ}$ до $50^{\circ}$ северной широты (с.ш.) и от $30^{\circ}$ до $60^{\circ}$ восточной долготы (в.д.) и выглядят довольно неоднородно (рис. 1). Для решения ряда прикладных задач, в частности, классификации и районирования ПООС, классификации синоптических процессов исследуемый регион был разбит на 120 участков сетки с шагом по широте $1,5^{\circ}$ и/или 166,1 км и по долготе $-2,5^{\circ}$ и/или 275 км. 


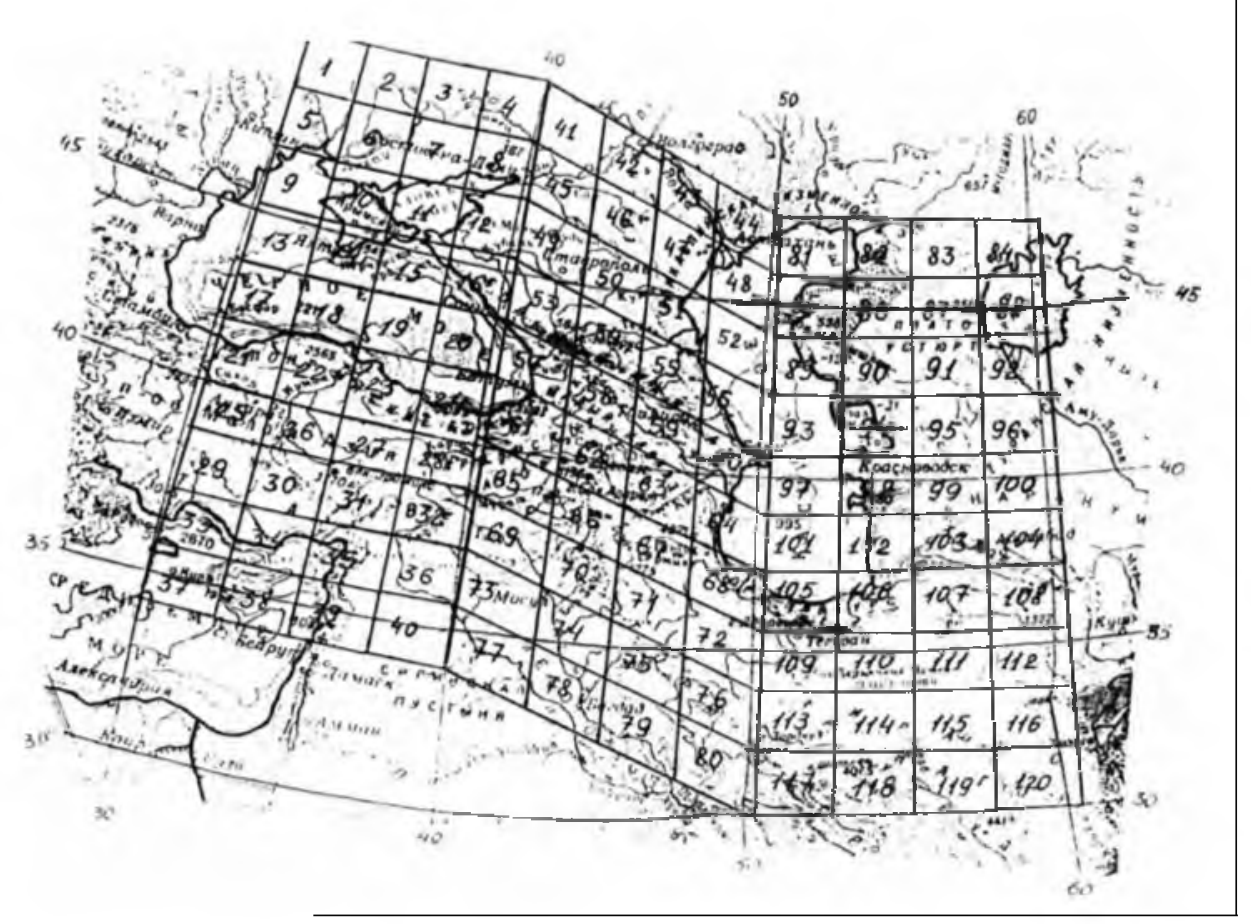

Рис. 1. Карта Кавказа и прилегающих территорий.

Fig. 1. The Map of the Caucasus and adjacent territories.

Серединная часть Кавказа наклонена вдоль Большого Кавказского хребта (рис. 1), являющегося естественной климатической границей между Северным Кавказом и Закавказьем, обуславливающей условия погоды в исследуемом регионе.

Западная часть Кавказа расположена с севера на юг. Она включает в себя: Подольскую равнину и Приднепровские возвышенности с максимальной высотой отдельных вершин до 300 м над уровнем моря (н.у.м.); Западную и Центральную части Черного моря; Понтийские горы (до 400 м н.у.м.), озеро Туз и восточные районы Средиземного моря.

Центральная часть Кавказа включает в себя:

Приволжскую возвышенность с высотами 150 м н.у.м. и Прикаспийскую низменность; Калмыцкие засушливые степи и Ставропольскую возвы- 
шенность (400 м н.у.м.); хребты Большого и Малого Кавказа (соответственно 5600 и 3700 м н.у.м); акватории восточных районов Черного и западных районов Каспийского морей.

Восточная часть Кавказа включает в себя:

Каспийское и Аральское моря; восточные районы Туранской низменности и Саракомышской впадины; пески Каракумы, хр. Копетдаг (3100 м н.у.м.) и Иранское нагорье (3500 м н.у.м.).

Такое разнообразие форм рельефа и физико-географических особенностей исследуемого региона Кавказа и прилегающих территорий способствовало:

-
-
совмершенствовононог существующих и разработке новых
методов классификации ПООС и синоптических процес-
сов, методов районирования ПООС по данным визуальных
наблюдений, контактных измерений и дистанционных ме-
тодов зондирования атмосферы.

Визуальные наблюдения проводились наземными метеорологическими станциями и постами, а контактные измерения - самолетами метеолабораториями (СМЛ). Дистанционные методы зондирования атмосферы осуществлялись неавтоматизированными и полуавтоматизированными метеорологическими радиолокационными станциями - «МРЛ-АСУ» и искусственными спутниками Земли (ИСЗ).

В представленной работе информация по облачности основана на дешифрировании снимков ИСЗ (ИК-информация). Горизонтальная протяженность оценивалась по макроструктуре изображения; высота верхней границы и вертикальная мошность облачности - по различию в яркости изображения снимков ИСЗ [4, 12, 29]; мезоструктура снимков - по вторичным признакам, особенности которых учитывались при уточнении типа (балла) облачной системы.

Целью работы является совершенствование методов классификации ПООС, районирования ПООС и синоптических процессов Кавказа и прилегающих территорий.

\section{Материалы и методы исследований}

Привлекались:

184 снимков облачности ИС3 NOAA (National Oceanic and Atmospheric Administration) 92 дня летнего сезона 1981 г., полученные в ночное (20 ч. МСК) и дневное (8 ч. МСК) 
время суток для 120 участков сетки Кавказа и прилегающих территорий; приземные синоптические карты погоды (кольцевые и основные) и высотные карты барической топографии Грузинского Республиканского управления гидрометеорологической службы;

физико-статистические методы исследования, с помощью которых осуществлялись совершенствование существующих и разработка новых методов классификации и районирования ПООС, классификации синоптических процессов Кавказа и прилегающих территорий.

\section{Результаты исследований и их обсуждение}

\section{Классификация ПООС по данным снимков ИСЗ}

В существующем методе классификации ПООС в качестве количественного показателя их макроструктурных особенностей привлекался номер типа (балла) облачности [27]. В результате количественного нефанализа снимков ИСЗ было выделено 4 типа (7 баллов) облачностей:

тип I (0-1 балл) это незначительная облачность; тип II (2-3 балла) - небольшая облачность; тип III (4-5 баллов) - значительная облачность; тип IV (6-7 баллов) - облачные полосы и вихри.

Недостатком существующего метода классификации ПООС, разработанного в [27-29] является не учет в нем интенсивности протекающих в атмосфере процессов, сопровождающихся ливнями, грозами, градобитиями и шквалами различной силы. Для решения поставленной задачи проводились специальные исследования:

данные облачности, полученные со снимков ИСЗ, сопоставлялись с соответствующей фактической погодой на метеостанциях и постах, расположенных в различных районах участков сетки Грузии с №№ 57-63 (рис. 1) [4, 5, 12, 21].

Полученные результаты в дальнейшем обобщались для 120 участков сетки Кавказа и прилегающей территории (рис. 1).

С учетом классификации ПООС, сопровождающихся атмосферными процессами и характеризующимися черно-белыми и цветными изображениями снимков ИСЗ, были количественно оценены не только 7 типов (7 баллов) облачности участка сетки (табл. 1), но и интенсивность атмосферных процессов, протекающих в них.

Тип I (0-1 балл) это незначительная облачность без осадков; тип II (2-3 балла) - отдельные изолированные облака хорошей погоды; тип III (4- 
5 баллов) - значительная облачность перистых облаков; тип IV (6-7 баллов) белая облачность в окклюдированном циклоне и заполняющейся ложбине; тип V (6-7 баллов) - кучево-дождевая облачность в виде округлых пятен; тип VI (6-7 баллов) - яркая белая облачность в виде фронтальной полосы; тип VII (6-7 баллов) - яркая белая облачность в облачных вихрях, связанных с молодым циклоном и активной зоной конвергенции.

I типом облачности интенсивностью:

0 баллов оценивается безоблачная площадь сетки и незначительная облачность, занимающая менее $20 \%$ этой площади, а 1 балл - незначительная облачность однородного темно-серого цвета, занимающей более $20 \%$ участка сетки, к которой относятся тонкие туманы, низкая слоистая облачность $(\mathrm{St})$ над водными или земными поверхностями (2. $\square$ Слоист. обл., табл. 1-2).

II типом облачности интенсивностью:

2 балла оцениваются густые туманы и $\mathrm{St}$, отдельные изолированные облака хорошей погоды, включающие в себя $\mathrm{Cu}$, Ac, CuCong (1. $\square$ Обл. в. ср. яр., табл. 1-2) и занимающие площади участков сетки от $20 \%$ до $80 \%$, а 3 балла - облачность, занимающая площади участков сетки более $80 \%$ и сопровождающаяся выпадением моросящих осадков и слабыми осадками (3. $\square$ Ос. слаб., табл. 1-2).

III типом облачности интенсивностью:

4 балла оцениваются облачные системы перистых облаков $(\mathrm{Ci}, \mathrm{Cs}$ и $\mathrm{Cc})$, занимающие площади сетки от $20 \%$ до $80 \%$ без осадков, а 5 баллов - облачные системы Ci, Cs и Cc, занимающие площадь сетки более $80 \%$ без осадков

IV типом облачности интенсивностью:

6 баллов оценивается белая облачность, развивающаяся в окклюдированном циклоне (сочетание теплых и холодных воздушных масс) и заполняющейся ложбине на площади сетки от $20 \%$ до $80 \%$, а 7 баллов - белая облачность на площади более $80 \%$.

Теплые воздушные массы характеризуются облачной системой Sc-As-Ns, сопровождающиеся слабыми осадками (3. [ табл. 1-2). 
Холодные воздушные массы характеризуются облачной системой Ns$\mathrm{As}-\mathrm{Cb}$ и $\mathrm{Cb}-\mathrm{Ac}$, сопровождающихся умеренными ливнями (8. П Лив. умер., табл. 1-2), грозами (11. Ш Гроза R), табл. 1-2), градом (14. Г Град умер., табл. 1-2) и шквалами (17. В Гроз + Шкв умер. табл. 1-2), табл. 1-2.

V типом облачности интенсивностью:

6 баллов оценивается кучево-дождевая облачность $(\mathrm{Cb})$ в виде округлых пятен, развивающейся при внутримассовых процессах на площади сетки от $20 \%$ до $80 \%$, а 7 баллов - $\mathrm{Cb}$ на площади сетки более $80 \%$.

Из $\mathrm{Cb}$ отмечается выпадение кратковременных умеренных ливней (8. Лив. умер., табл. 1-2) и града (14. П Град умер., табл. 1-2), сопровождающихся умеренными грозами (11. Ш Гроза R), табл. 1-2) и шквалами (17. В Гроз + Шкв умер., табл. 1-2).

VI типом облачности интенсивностью:

6 баллов оценивается яркая белая облачность, развивающаяся в виде фронтальной полосы на площади сетки от $20 \%$ до $80 \%$, а 7 баллов - яркая белая облачность на площади сетки более $80 \%$.

Теплые фронты характеризуются облачной системой ScAs-Ns, сопровождающейся умеренными ливнями (8. Лив. умер., табл. 1-2) и грозами (11. Ш Гроза R), 17. Ш Гроз + Шкв умер., табл. 1-2).

Холодные медленно и быстродвижущиеся фронты характеризуются облачными системами $\mathrm{Ns}-\mathrm{As}-\mathrm{Cb}$ и $\mathrm{Cb}-\mathrm{Ac}$, сопровождающихся сильными ливнями (9. Лив. сильн., табл. 1-2), грозами (12. Гроза R, табл. 1-2), градом (15. Г Град сильн., табл. 1-2) и шквалами со скоростью более 25 м/с (18. $\square$ Гроз + Шкв сильн., табл. 1-2).

VII типом облачности интенсивностью:

6 баллов оценивается яркая белая облачность в облачных вихрях, связанная с молодым циклоном и активной зоной конвергенции на площади сетки с просветом от $20 \%$ до $80 \%$, а 7 баллов - более яркая белая облачность на площади сетки более $80 \%$.

Это наиболее мощные облака фронтального происхождения с высотами верхней границы 10 и 12 км и мощностями 8 и 10 км, наблюдаемыми, соответственно в ночное и дневное время суток (табл. 1).

Такой тип облачности сопровождается сильными ливнями (9. 
Таблица 1. ЗАВИСИМОСТЬ ВЫСОТЫ ВЕРХНЕЙ ГРАНИЦЫ (НВ) И МОЩНОСТИ $(\triangle H)$ ПООС ОТ СИНОПТИЧЕСКОЙ СИТУАЦИИ И ЯРКОСТИ ИЗОБРАЖЕНИЯ (БАЛЛЫ) СНИМКОВ ИСЗ $[4,5,27,29]$ Table 1. THE DEPENDENCE OF THE UPPER LIMIT HEIGHT (HB) AND POWER $(\triangle H)$ OF CFCS ON SYNOPTICAL SITUATION AND AES IMAGES LUMINANCE $[4,5,27,29]$

\begin{tabular}{|c|c|c|c|c|c|c|c|}
\hline \multirow[t]{3}{*}{ Тип ПООС } & \multirow{3}{*}{$\begin{array}{l}\text { Характеристика } \\
\text { ПоОС }\end{array}$} & \multicolumn{5}{|c|}{ Параметры ПООС } & \multirow[t]{3}{*}{ Явление } \\
\hline & & \multirow[t]{2}{*}{ Баллы } & \multicolumn{2}{|l|}{ Ночь } & \multicolumn{2}{|l|}{ День } & \\
\hline & & & Нв, км & D & HB, KM & D & \\
\hline $\begin{array}{l}\text { I. } \\
\text { Безоблачная } \\
\text { погода }\end{array}$ & $\begin{array}{l}\text { 1. Ясная } \\
\text { погода } \\
\text { 2. Тонкие } \\
\text { туманы }\end{array}$ & $\begin{array}{l}0 \\
1\end{array}$ & - & - & - & - & $\begin{array}{l}\text { Без осадков } \\
\text { Без осадков }\end{array}$ \\
\hline $\begin{array}{l}\text { ІІ. } \\
\text { Отдельные } \\
\text { изолированные } \\
\text { облака хорошей } \\
\text { погоды }\end{array}$ & $\begin{array}{l}\text { 1. Менее } \\
\text { яркая } \\
\text { облачность } \\
\text { 2. Более } \\
\text { яркая } \\
\text { облачность }\end{array}$ & 3 & 3 & 2 & 5 & $\begin{array}{l}2 \\
3\end{array}$ & $\begin{array}{l}\text { 1. } \square \text { Обл. в. ср. яр. } \\
\text { 3. } \square \text { Ос. слаб. }\end{array}$ \\
\hline $\begin{array}{l}\text { III. } \\
\text { Перистые } \\
\text { облака }\end{array}$ & $\begin{array}{l}\text { 1. Участки } \\
\text { наименее } \\
\text { яркой } \\
\text { облачности } \\
2 . \text { Участки } \\
\text { менее } \\
\text { яркой } \\
\text { облачности }\end{array}$ & 5 & 5 & 0,5 & 8 & 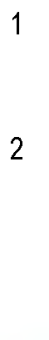 & Без осадков \\
\hline $\begin{array}{l}\text { IV. } \\
\text { Белая облачность } \\
\text { в окклюдированном } \\
\text { циклоне и } \\
\text { заполняющейся } \\
\text { ложбине }\end{array}$ & $\begin{array}{l}\text { 1. Участки } \\
\text { менее яркой } \\
\text { облачности } \\
\text { 2. Участки } \\
\text { более яркой } \\
\text { облачности }\end{array}$ & 7 & 3 & 3 & 8 & 5 & $\begin{array}{l}\text { 3. } \square \text { Ос. слаб. } \\
\text { 7. } \square \text { Лив. слаб., } 10 . \\
\square \text { Гроза (R), } 13 . \\
\text { Град слаб., } 16 . \\
\square \text { Гроз + Шкв слаб. }\end{array}$ \\
\hline $\begin{array}{l}\text { V. } \\
\text { Кучево-дождевая } \\
\text { облачность в виде } \\
\text { округлых пятен }\end{array}$ & $\begin{array}{l}\text { 1. Менее } \\
\text { яркая } \\
\text { облачность } \\
\text { на фоне } \\
\text { слоистой и } \\
\text { перистой } \\
\text { облачности. } \\
\text { 2. Яркая } \\
\text { облачность } \\
\text { с яркими } \\
\text { границами }\end{array}$ & 7 & 10 & 8 & 12 & 10 & $\begin{array}{l}\text { 8. } \square \text { Лив. умер., } \\
\text { 11. } \square \text { Гроза R), } 14 . \\
\text { Град умер., } 17 . \\
\text { Гроз+Шкв умер. } \\
\text { 9. П Лив. сильн., } \\
\text { 12. } \square \text { Гроза R, } 15 . \\
\square \text { Град сильн., } 18 . \\
\text { Гроз+Шкв сильн. }\end{array}$ \\
\hline
\end{tabular}




\begin{tabular}{|c|c|c|c|c|c|c|c|}
\hline \multirow[t]{3}{*}{ Тип ПООС } & \multirow{3}{*}{$\begin{array}{l}\text { Характеристика } \\
\text { поОС }\end{array}$} & \multicolumn{5}{|c|}{ Параметры ПООС } & \multirow[t]{3}{*}{ Явление } \\
\hline & & \multirow[t]{2}{*}{ Баллы } & \multicolumn{2}{|l|}{ Ночь } & \multicolumn{2}{|l|}{ День } & \\
\hline & & & Нв, км & D & Нв, кM & $\mathrm{D}$ & \\
\hline \multirow[t]{2}{*}{$\begin{array}{l}\text { VI. } \\
\text { Яркая белая } \\
\text { облачность в виде } \\
\text { фронтальной } \\
\text { полосы }\end{array}$} & $\begin{array}{l}\text { 1. Участки } \\
\text { менее яркой } \\
\text { облачности }\end{array}$ & 6 & 6 & 3 & 8 & 5 & $\begin{array}{l}\text { 7. } 1 \text { Лив. слаб., } 10 . \\
\square \text { Гроза (R), } 13 . \\
\square \text { Град слаб., } 16 . \\
\square \text { Гроз + Шкв слаб. } \\
\text { 8. Шив. умер., }\end{array}$ \\
\hline & $\begin{array}{l}\text { 2.Участки } \\
\text { более яркой } \\
\text { облачности }\end{array}$ & 7 & 8 & 6 & 10 & 8 & $\begin{array}{l}\text { 11. П Гроза R), } 14 . \\
\text { Град умер., } 17 . \\
\text { Гроз + Шкв умер. }\end{array}$ \\
\hline $\begin{array}{l}\text { VII. Яркая белая } \\
\text { облачность } \\
\text { в облачных вихрях, } \\
\text { связанных } \\
\text { с молодым }\end{array}$ & $\begin{array}{l}\text { 1. Участки } \\
\text { менее яркой } \\
\text { облачности }\end{array}$ & 6 & 8 & 6 & 10 & 8 & $\begin{array}{l}\text { 8. П Лив. умер., } \\
\text { 11. Ш Гроза R), } 14 . \\
\text { Град умер., } 17 . \\
\text { Гроз+Шкв умер. } \\
\text { 9. Пив. сильн., }\end{array}$ \\
\hline $\begin{array}{l}\text { циклоном и активной } \\
\text { зоной конвергенции }\end{array}$ & $\begin{array}{l}\text { 2.Участки } \\
\text { более яркой } \\
\text { облачности }\end{array}$ & 7 & 10 & 8 & 12 & 10 & 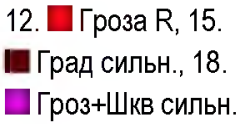 \\
\hline
\end{tabular}

Таблица 2.

ШКАЛА ОЦЕНКИ ОПАСНЫХ ЯВЛЕНИЙ ПОГОДЫ ПО ДАННЫМ СНИМКОВ ИСЗ НА 16.07.2019

Table 2. THE ESTIMATION SCALE OF DANGEROUS WEATHER PHENOMENA ACCORDING TO AES DATA 16.07.2019

\begin{tabular}{|c|c|c|}
\hline 1. $\square$ Обл. в.ср. яр. & 7. П Лив. слаб. & 13. Ш Град слаб. \\
\hline 2. Б Слоист. обл. & 8. Лив. умер. & 14. 口Град умер. \\
\hline 3. $\square$ Ос. слаб. & 9. Лив. сильн. & 15. 口 Град сильн. \\
\hline 4. 口 Oc. умер. & 10. $\square$ Гроза (R) & 16. $\square$ Гроз + Шкв слаб. \\
\hline 5. Ф Ос. сильн. & 11. $\square$ Гроза R) & 17. $\square$ Гроз + Шкв умер. \\
\hline 6. [] Куч. обл. & 12. Гроза R & 18. Ш Гроз + Шкв сильн. \\
\hline
\end{tabular}

Лив. сильн., табл. 1-2), грозами (12. — Гроза R, табл. 1-2), градобитиями (15. Град сильн., табл. 1-2) и шквалами со скоростью более $25 \mathrm{~m} / \mathrm{c}$ (18. 口 Гроз + Шкв сильн., табл. 1-2).

Таким образом, в результате обработки и нефанализа снимков ИСЗ, был создан архив численных карт облачных 
ситуации в количестве 184 снимков ИСЗ, куда вошли наиболее мощные облака фронтального происхождения с высотами верхней границы 10-12 км и более, сопровождающиеся интенсивными ливнями, сильными шквалами (более 25 м/с) при грозе и выпадении града, достигающего в некоторых случаях катастрофических размеров (более 5 см) [1, 3-10].

Полученные в таблице 1 результаты классификации ПООС в дальнейшем обобщались и для остальных участков сетки Кавказа и прилегающих территорий и легли в основу разработки методов классификации ПООС, районирования ПООС и синоптических процессов по данным снимков ИСЗ.

\section{Районирование Кавказа и прилегающих территорий по данным снимков облачности ИСЗ}

В основу районирования Кавказа и прилегающих территорий был положен метод объективной классификации ПООС (п. 2.1). Он может быть привлечен, когда число классов, на которое необходимо разбить совокупность, заранее известно [27]. Его можно получить, исходя из физико-географических особенностей исследуемого региона, характеризующихся определенными количественными критериями оценки. В качестве таковых использовался номер типа (балла) облачности [27, 29].

Районирование ПООС рассматривалось в $[15,18,26]$. В представленной работе районирование ПООС формулировалось, как задача:

определения климатической (природной) повторяемости существования тех или иных типов (баллов) облачности с учетом опасных явлений погоды [4];

объединения идентичных участков сетки исследуемого региона (в каждом участке сетки природные вероятности существования общей облачности и облачности различных типов рассчитывались, как отношения числа случаев соответствующих типов (баллов) облачности к общему числу наблюдений (184 случая).

Идентичность определялась по гистограмме (рис. 2), где на оси абсцисс $(x)$ отложены номера типов, а на оси ординат $f(x)$ - соответствующие частоты $[5,27,29]$. Если для соседних участков сетки виды кривой гистограммы одинаковы, то такие участки сетки могут быть объединены в один район. Если учесть, что распределения вероятностей безоблачных и облачных ситуаций в каждом участке сетки имеют положительную асимметрию, то в качестве критерия сходства достаточно взять одинаковое распределение сочетаний трех типов (баллов) облачности (II, III, IV), исключая тип I. На первом месте ставится номер типа (балла) облачности, имеющего наибольшее значение вероятности, а на третьем месте - номер типа (балла) облачности с наименьшим значением вероятности. 
Получены шесть сочетаний типов (баллов) облачности (рис. 2):

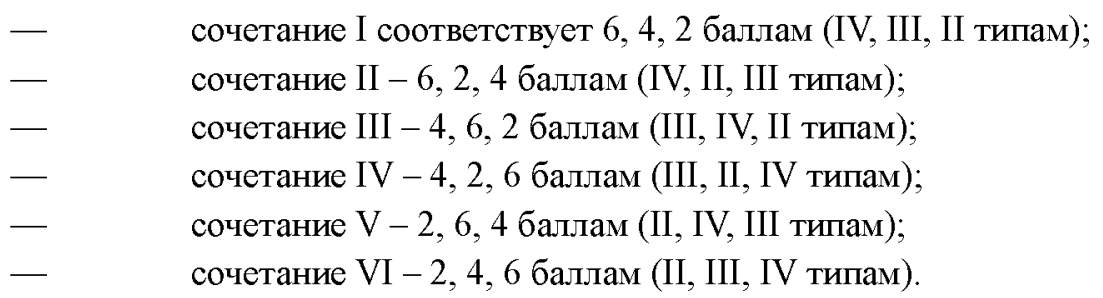

Сочетания ранжированы по мере убывания интенсивности облачности. На рисунке 3 числу 6 соответствует значение интенсивности облачности 6 и 7 баллов, числу $4-4$ и 5 балла, а числу 2 - 2 и 3 балла.

В результате анализа гистограмм повторяемости типов облачности, построена карта районирования Кавказа и прилегающей территории по облачности (рис. 2). Анализ этого рисунка позволил выявить следующее. Несмотря на идентичность участков сетки по виду кривой гистограммы, суммарная природная вероятность формирования общей облачности в них оказалась разной.

Например, для района, характеризующегося ранжированными значениями общей облачности по баллам 2, 4, 6 (типам II, III, IV), приведенной на рисунке 3 (Уо. 6) вероятность ее формирования $(P)$ колеблется от 7\% (Сирийская пустыня) до 73\% (южные склоны Кавказа).

Анализируя вероятностные карты формирования облачности различных типов можно заметить, что максимум вероятности:

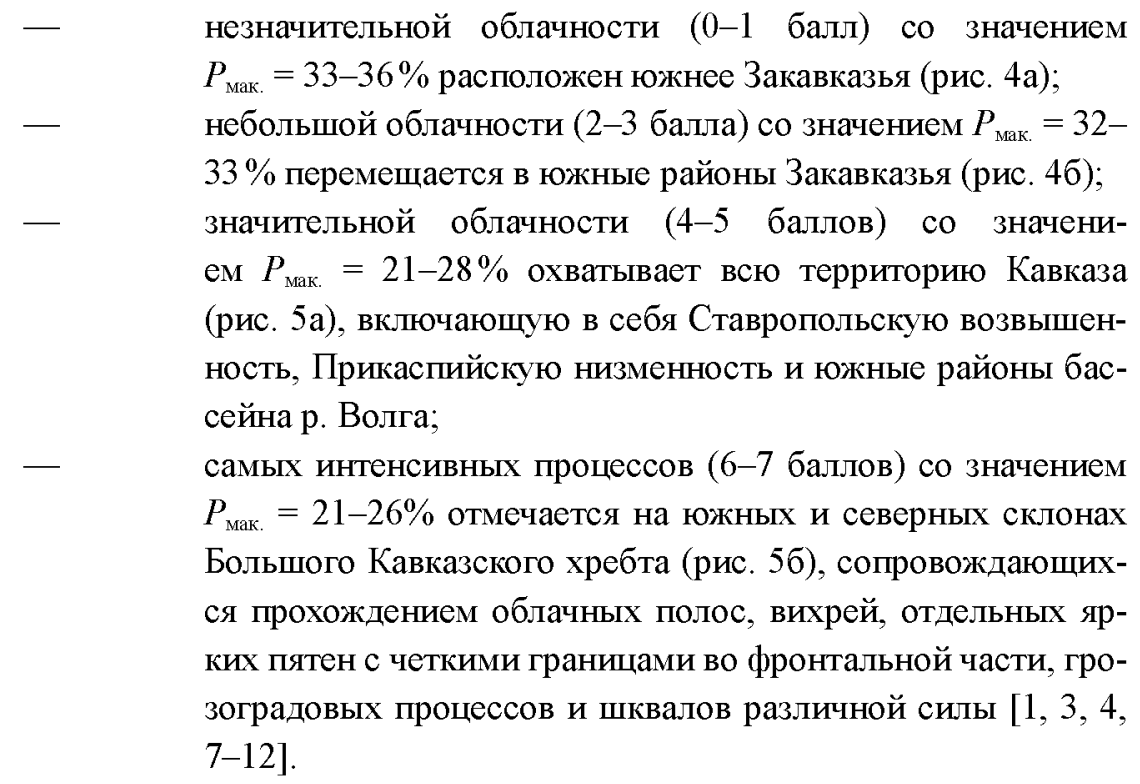

Анализ построенных вероятностных карт общей облачности и облачности различных типов позволяет сделать вывод о том, что их про- 


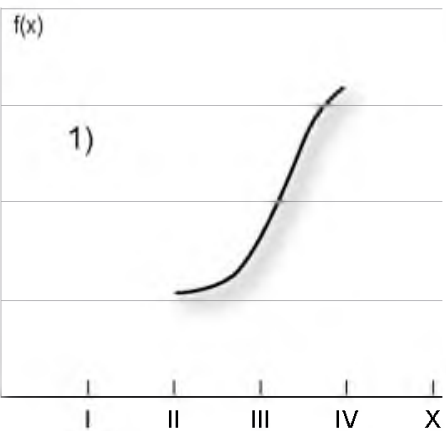

$f(x)$

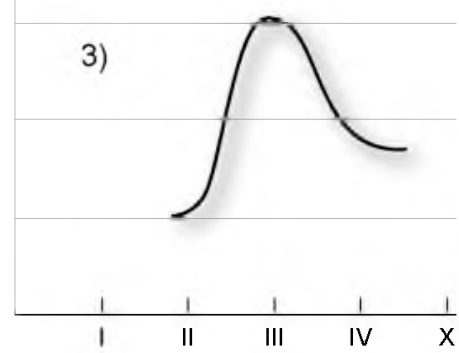

$f(x)$

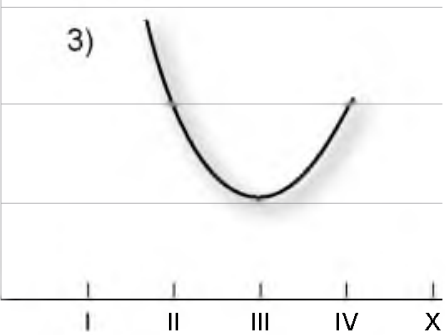

$f(x)$

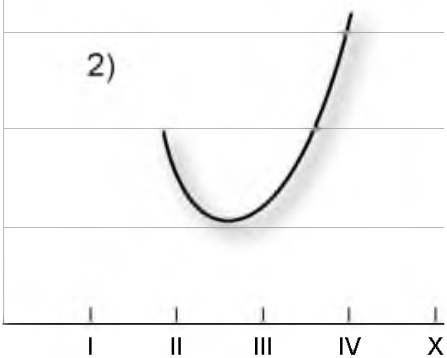

$f(x)$

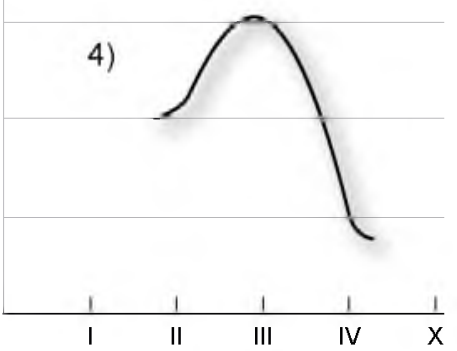

$f(x)$

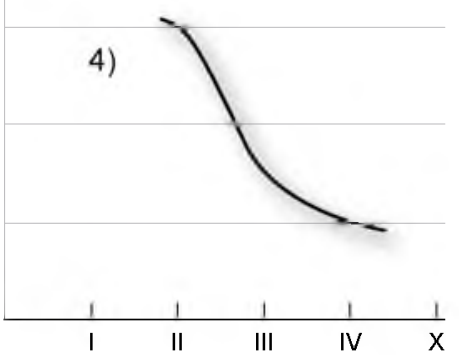

Условные обозначения (Уо) (Explanations):

1) - IV, III, II $(6,4,2) ; 2)-I V, I I, I I I(6,2,4)$

3) - III, IV, II $(4,6,2) ; 4)-I I I, I I, I V(4,2,6)$;

5) - II, IV, III $(2,6,4) ; 6)-I I, I I I, I V(2,4,6)$

Рис. 2.

Вероятностный вид распределения функции $\mathrm{f}(\mathrm{x})$ типов (баллов) облачности (х) в сетках карты Кавказа и прилегающей территории по данным снимков ИС3 [5, 27, 29].

Fig. 2. The probable view of distributing $f(x)$ types (cloud amounts) function of cloudiness $(x)$ in the charts of the map of Caucasus and adjacent territory according to the data of AES images $[5,27,29]$. 


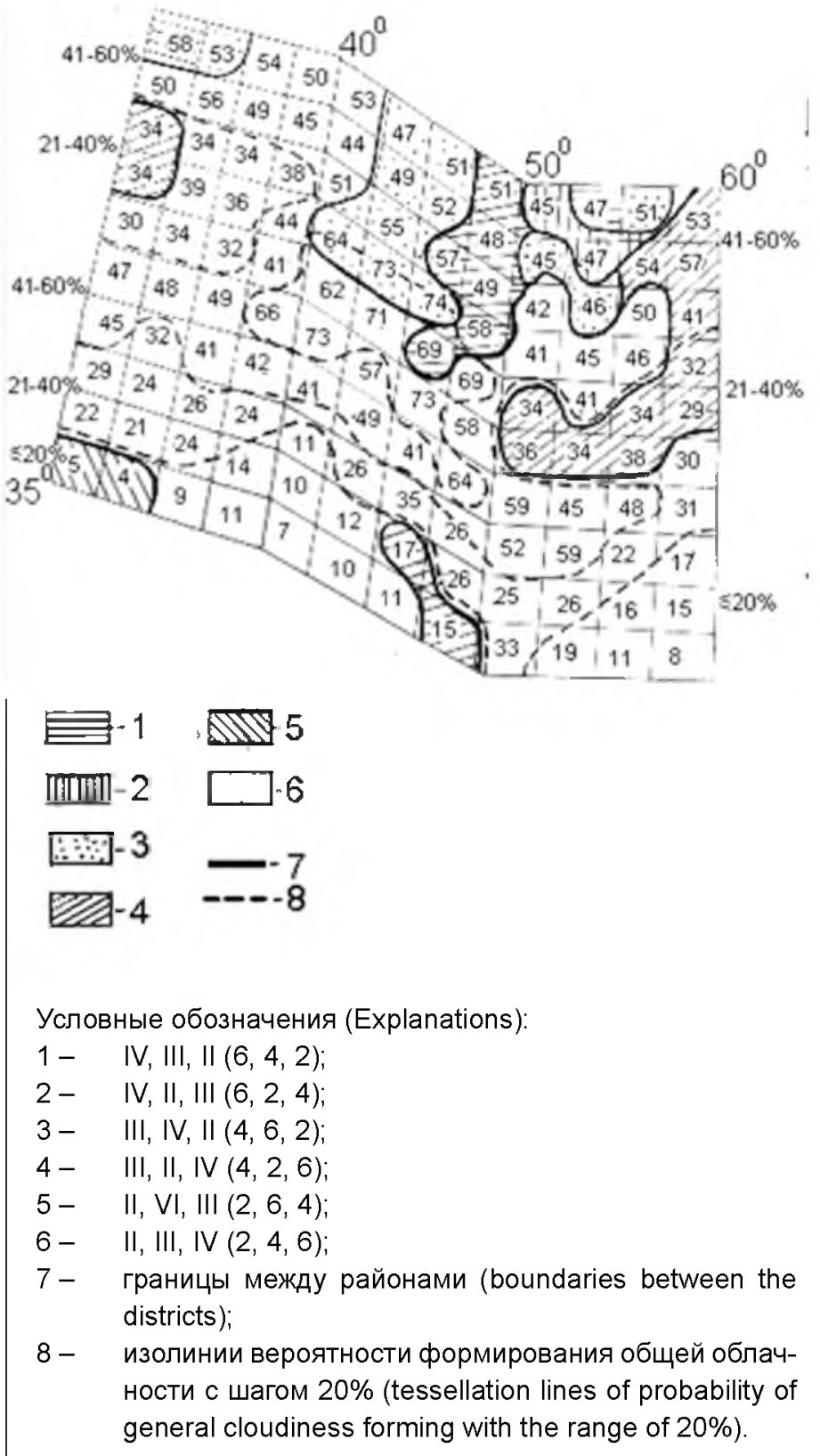

Рис. 3

Распределение вероятности (\%) формирования общей облачности на Кавказе и прилегающей территории в зависимости от сочетания типов (баллов) облачных ситуаций.

Fig. 3. The distribution of probability (\%) of forming general cloudiness in the Caucasus and adjacent territory depending on the combination of types (cloud amounts) of cloud situations 


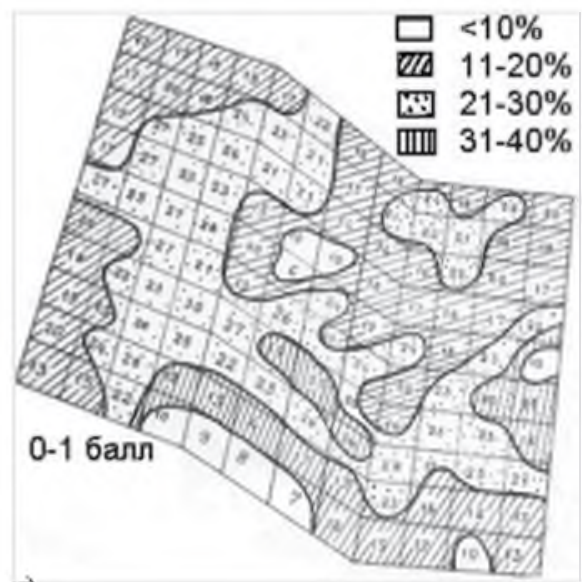

a)

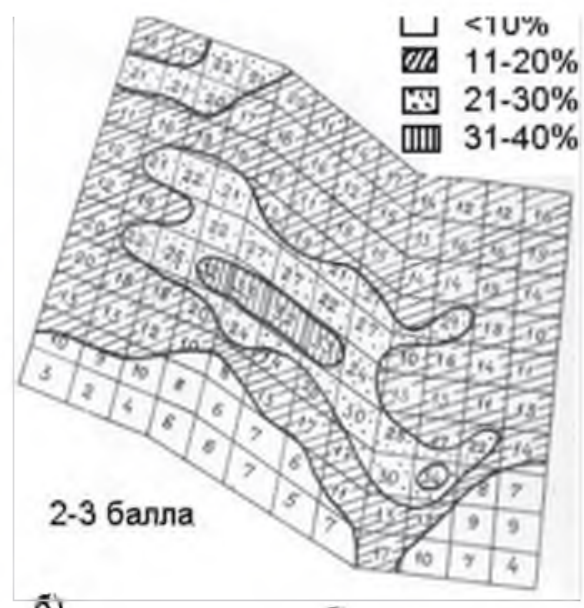

6)

$$
\begin{aligned}
& \text { Условные } \\
& \text { обозначения: } \\
& \text { а) - І тип (0-1 балл); } \\
& \text { б) - II тип (2-3 балла); } \\
& -P \leq 10 \% \text {; } \\
& \text { ZD }-P=11-20 \% \text {; } \\
& \text { [1] }-P=21-30 \% \text {; } \\
& \text { [III] }-P>30 \%
\end{aligned}
$$

Рис. 4.

Распределение вероятности (\%) формирования облачности I типа (0-1 балл) и II типа (2-3 балла) на Кавказе и прилегающих территориях.

Fig. 4. The distribution of formation probability (\%) of the I-st (0-1 points) and II-nd (2-3 points) cloudiness types in the Caucasus and adjacent territories Explanations.

странственная изменчивость в большей степени определяется физико-географическими особенностями подстилающей поверхности, чем масштабом синоптических процессов.

Именно по этой причине на Кавказе обостряются грозоградовые процессы, достигающие наибольшей интенсивности в: 
a)

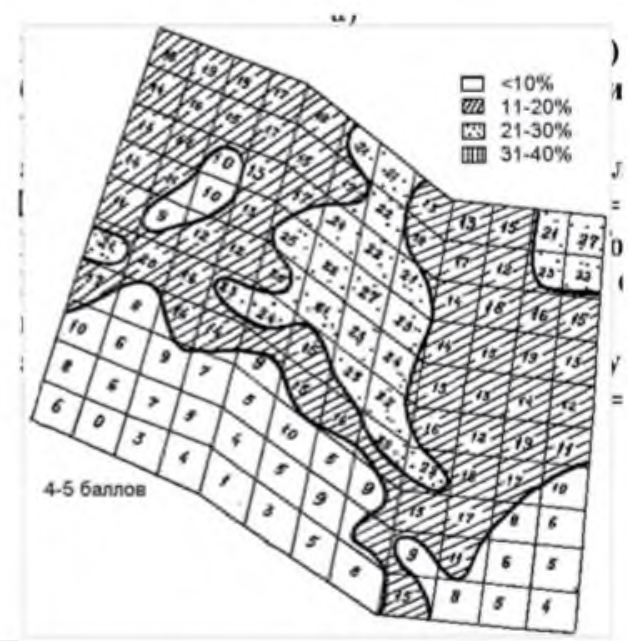

б)

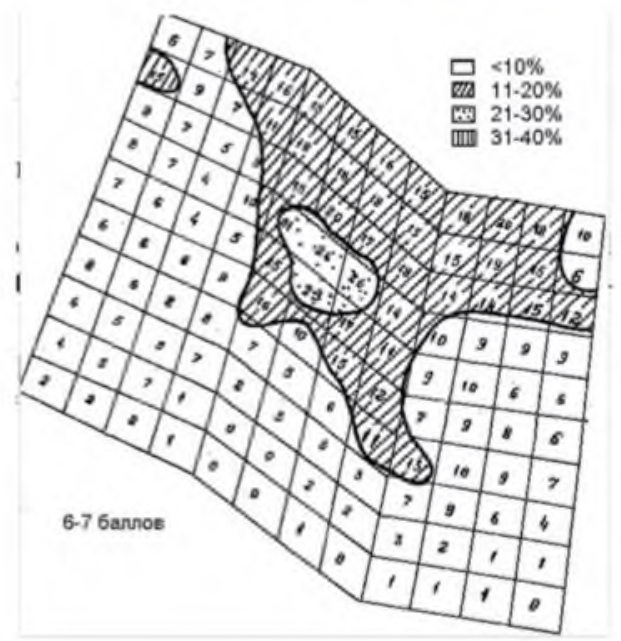

Условные обозначения (Explanations):

a) - III тип (4-5 баллов) [III-d type (4-5 cloud amounts];

б) - IV тип (6-7 баллов) [IV-th type (6-7 cloud amounts)];

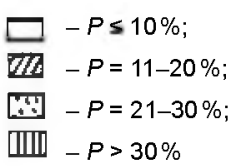

Рис. 5.

Распределение вероятности (\%) формирования облачности III типа (4-5 баллов) и IV типа (6-7 баллов) различных типов (баллов) на Кавказе и прилегающих территориях.

Fig. 5. The distribution of formation probability (\%) of the III-d (4-5 points) and IV-th (6-7 points) cloudiness types in the Caucasus and adjacent territories. 
- Российской Федерации (РФ), включающей в себя районы республик Карачаево-Черкессии, Кабардино-Балкарии, Северной Осетии, Краснодарского и Ставропольского края; Республике Грузия, включающей в себя районы Восточной Грузии (Квемо Картли и Кахети).

Построенные по данным снимков ИСЗ вероятностные карты распределения облачности с опасными явлениями погоды подтверждают выводы о том, что Центральный Кавказ был и остается по настоящее время одним из градоопаснейших регионов мира [1].

\section{Классификация синоптических процессов на Кавказе} и прилегающих территориях по данным снимков ИСЗ

В основу классификации синоптических процессов положен полу-автоматизированный метод классификации полей геопотенциала, алгоритм которого дан в $[6,27]$. В качестве количественного показателя макроструктурных особенностей полей облачности использовался номер типа (балла) облачности. Задача классификации синоптических процессов заключалась в оптимальном распределении элементов выборки по минимальному числу классов, которые определялись в процессе решения самой задачи классификации синоптических процессов [27].

При решении поставленной задачи данные количественных карт облачности, состоящих из 120 участков сетки, были представлены в виде 120 мерного вектора (рис. 1). Каждому вектору, описывающему облачную ситуацию, ставили в соответствии массив, описывающий синоптическую ситуацию.

В предложенном методе классификации синоптических процессов весь архив облачности (184 снимков облачности ИСЗ для 120 участков сетки) был разделен на 9 типов (классов) с векторами-эталонами, которым, в зависимости от направления перемещения облачности над Кавказом и прилегающих территориях, были присвоены следующие имена [6]: I типу - $K_{17}$, II типу $-K_{98}$, III - типу $K_{171}$, IV типу $-K_{176}$, V типу $-K_{8}$, VI типу $-K_{28}$, VII типу $-K_{69}$, VIII типу $-K_{24}$ и IX типу $-K_{63}$.

С учетом приведенных 9 типов (классов) облачности, включающих в себя: снимки ИСЗ (а), соответствующие численные карты облачности в баллах (б) и синоптические ситуации на высотных картах барической топографии $A T_{500}$ и $A T_{300}$ (в), дается физическая интерпретация предложенного совершенствованного метода синоптических процессов [6].

Согласно синоптическим картам погоды (СКП) от 09.06.1981 г. І тип $\left(K_{17}\right)$ облачности характеризуется размытым полем относительно повышенного давления, горизонтальный градиент которого направлен с востока на запад. В этом случае в восточных и юго-восточных районах Грузии возможно 

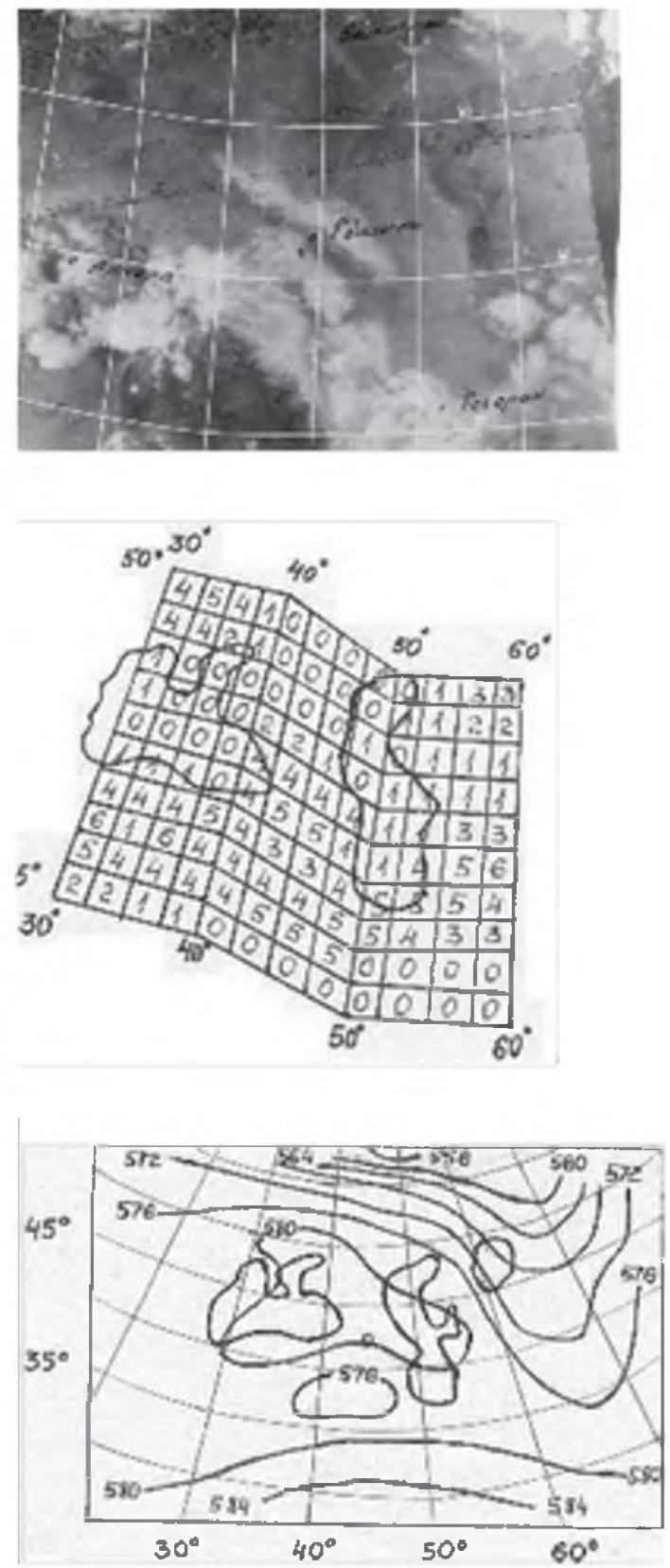

Pис. 6.

Тип I (K $\left.\mathrm{K}_{17}\right)$. Снимок облачности ИС3 (a), соответствующие численная карта облачности в баллах (б) и синоптическая ситуация на $\mathrm{AT}_{500}$ (B).

Fig. 6. Type I $\left(K_{17}\right)$. The cloudiness image of AES (a), corresponding numerical map of cloudiness in cloud amounts (b) and synoptical situationat $\mathrm{AT}_{500}$ (c). 
развитие незначительной облачности и осадков (рис. 6).

Для этого типа характерна установившаяся погода.

Согласно СКП от 09.06.1981 г. II тип $\left(K_{98}\right)$ облачности характеризуется тем, что в:

восточных районах исследуемой территории наблюдается поле относительно низкого давления, ось которого направлена с северо-северо-востока на восточную Грузию;

западных районах Чёрного моря - поле высокого давления, которое препятствует вторжению холодных воздушных масс из районов Восточной Грузи в Западную;

в юго-восточных районах Грузии - фронтальные разделы с интенсивным развитием кучево-дождевой облачности, сопровождающейся умеренными и сильными осадками (рис. 7).

Этот тип соответствует восточному типу погоды над Закавказьем.

Согласно СКП от 25.08.1981 г. III тип $\left(K_{171}\right)$ облачности характеризуется тем, что на:

северо-северо-востоке от Кавказа наблюдается поле относительно пониженного давления, а с юга в северном направлении - поле относительно повышенного давления; Восточную Грузию с восточной Европы слабо действует ложбина северо-западного направления.

Такое расположение осей ложбины и гребня способствует формированию слабых фронтальных процессов в районах Восточной Грузии (рис. 8). Этот процесс соответствует северному типу погоды над Закавказьем.

Согласно СКП от 27.08.1981 г. IV тип $\left(K_{176}\right)$ характеризуется тем, что: районы Восточной Грузии находятся под влиянием относительно высокого давления, ось которого направлена с югоюго-запада на северо-северо-восток; вторжение холодных воздушных масс на исследуемую территорию отмечается с северо-запада; развитие облачности в Восточной Грузии не отмечается (рис. 9).

Этот процесс соответствует северо-западному типу погоды. Согласно СКП от 04.06.1981 г. V тип $\left(K_{8}\right)$ характеризуется тем, что: над Чёрным морем на $A T_{500}$ и $A T_{300}$ наблюдается углубляющаяся ложбина, ось которой направлена с северо-северовостока на юго-юго-запад; 

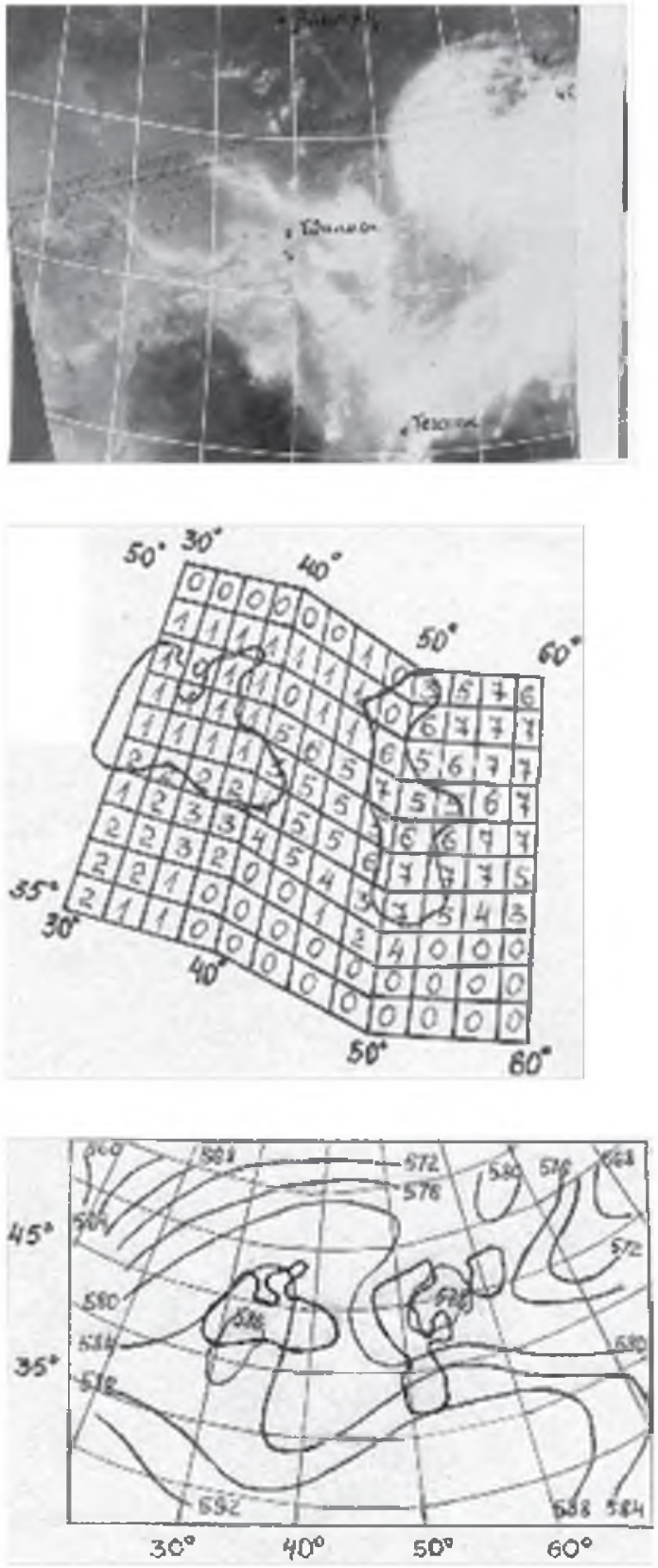

Рис. 7.

Тип II ( $\left.\mathrm{K}_{98}\right)$. Снимок облачности ИС3 (a), соответствующие численная карта облачности в баллах (б) и синоптическая ситуация на $\mathrm{AT}_{500}$ (в).

Fig. 7. Type II $\left(K_{98}\right)$. The cloudiness image of AES (a), corresponding numerical map of cloudiness in cloud amounts (b) and synoptical situation at $A T_{500}$ (c). 

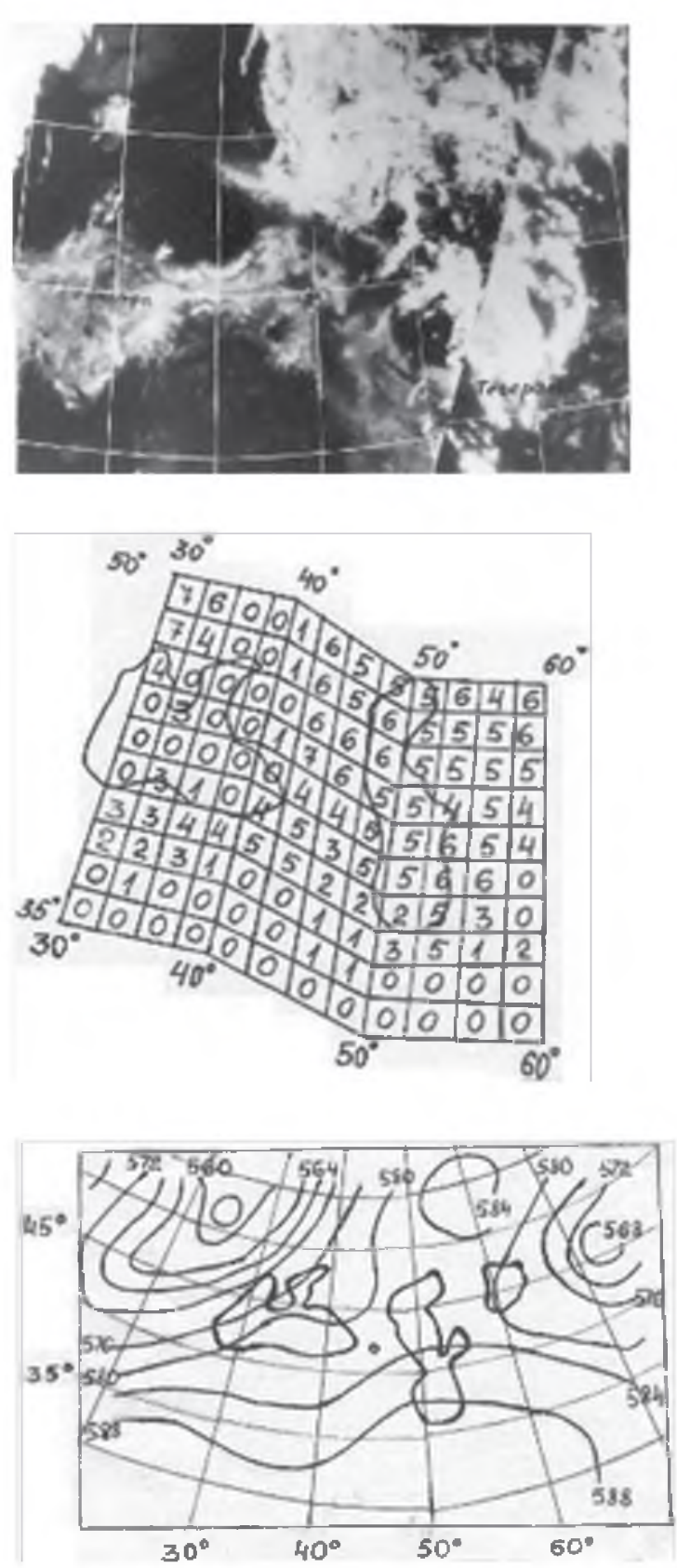

Рис. 8.

Тип III ( $\left.\mathrm{K}_{171}\right)$. Снимок облачности ИС3 (а), соответствующие численная карта облачности в баллах (б) и синоптическая ситуация на $\mathrm{AT}_{500}$ (B).

Fig. 8. Type III $\left(K_{171}\right)$. The cloudiness image of AES (a), corresponding numerical map of cloudiness in cloud amounts (b) and synoptical situation at $A T_{500}(c)$. 

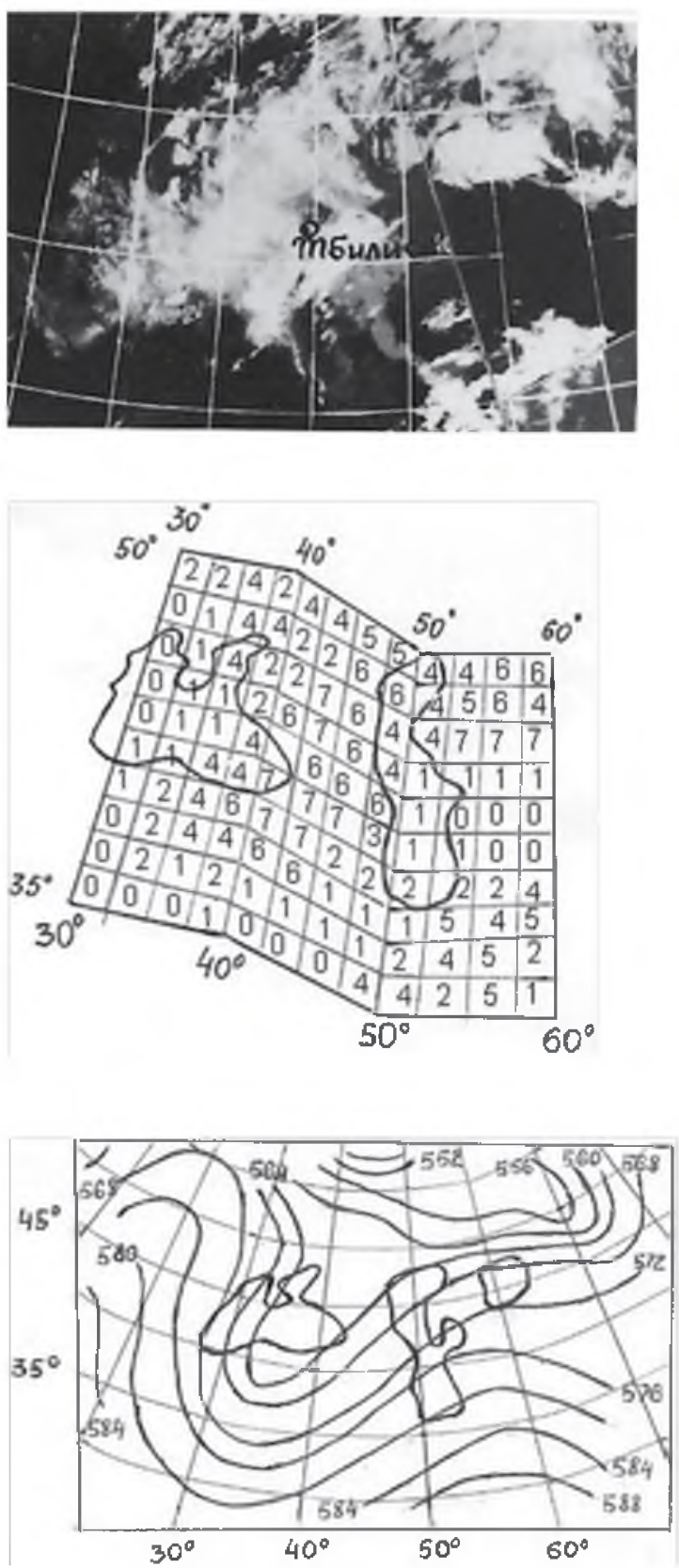

Рис. 9.

Tип IV (K $\left.\mathrm{K}_{176}\right)$. Снимок облачности ИС3 (a), соответствующие численная карта облачности в баллах (б) и синоптическая ситуация на $\mathrm{AT}_{500}$ (в).

Fig. 9. Type IV $\left(\mathrm{K}_{176}\right)$. The cloudiness image of AES (a), corresponding numerical map of cloudiness in cloud amounts (b) and synoptical situation at $A T_{500}$ (c). 
отмечается перемещение воздушных масс с юго-запада на северо-восток, то есть перпендикулярно к Большому и Малому Кавказскому хребтам.

Такая ситуация, за счет вынужденного подъема воздушных масс, способствует дополнительному развитию интенсивных вертикальных потоков, усилению фронтальных разделов и формированию кучево-дождевой облачности, сопровождающейся ливневыми осадками, грозами и градом (рис. 10). Этот тип погоды соответствует юго-западному типу погоды.

Согласно СКП от 23.08.1981 г. VI тип $\left(K_{28}\right)$ характеризуется тем, что:

- над Закавказьем наблюдастся молодой циклон;

- н с северо-западе и северо-востоке расположены поля относительно низкого давления, прослеживающиеся и на карте $A T_{300}$;

поля относительно высокого давления прослеживаются на юге и севере от Закавказья;

ось ложбины, находящаяся на северо-западе, проходит через западные районы Чёрного моря и направлена в сторону Грузии;

- $\quad$ ось гребня, находящаяся на юге направлена на Грузию.

Такое расположение барических полей способствует формированию фронтальных разделов над западными районами Чёрного моря, которые при прохождении над территорией Закавказья вызывают интенсивное развитие кучево-дождевой облачности (рис. 11). Этот тип соответствует западному типу погоды над Закавказьем.

Согласно СКП от 12.06.1981 г. VII тип $\left(K_{69}\right)$ характеризуется тем, что Закавказье находится в поле относительно высокого давления, а на северовостоке от него наблюдается поле низкого давления, ось которого направлена через Каспийское море в сторону восточных районов Грузии, хотя его влияние блокировано полем относительно высокого давления.

При таких ситуациях в восточных районах Грузии наблюдается развитие облачности сравнительно малой интенсивности (рис. 12). Этот тип можно отнести к северо-восточному типу погоды.

Согласно СКП от 02.07.1981 г.VIII тип $\left(K_{24}\right)$ характеризуется тем, что в южных районах Закавказья наблюдается поле относительно высокого давления, а с севера в сторону центральных районов направлена ось ложбины.

Такое расположение барических полей препятствует вторжению холодных воздушных масс с севера. В таких ситуациях развитие облачности возможно лишь на южных склонах Большого Кавказа (рис. 13). Этот тип соответствует юго-восточному типу погоды. 
a)

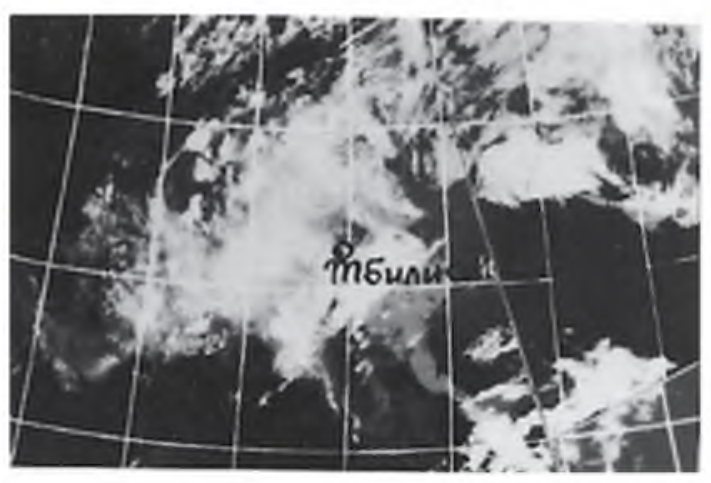

б)

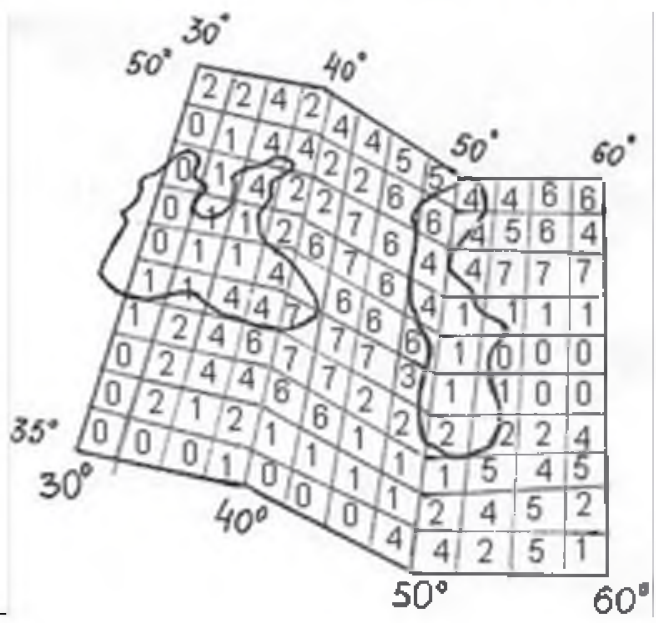

в)

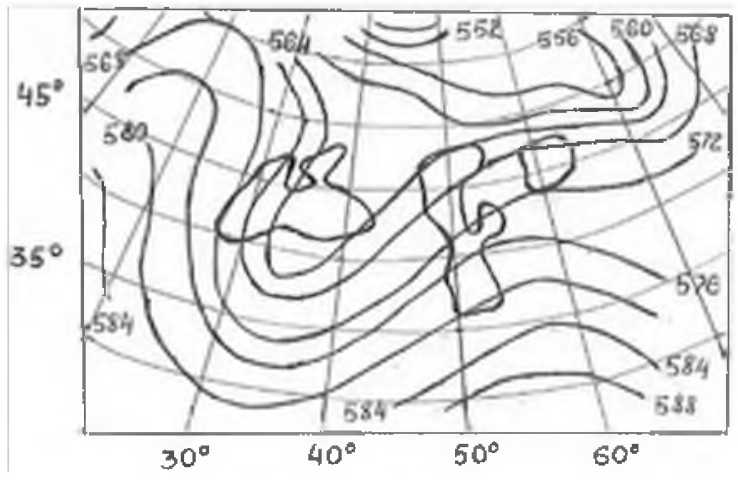

Рис. 10.

Тип V $\left(\mathrm{K}_{8}\right)$. Снимок облачности ИС3 (a), соответствующие численная карта облачности в баллах (б) и синоптическая ситуация на $\mathrm{AT}_{500}$ (в).

Fig. 10. Type $V\left(K_{8}\right)$. The cloudiness image of AES (a), corresponding numerical map of cloudiness in cloud amounts (b) and synoptical situation at $A T_{500}$ (c). 
a)

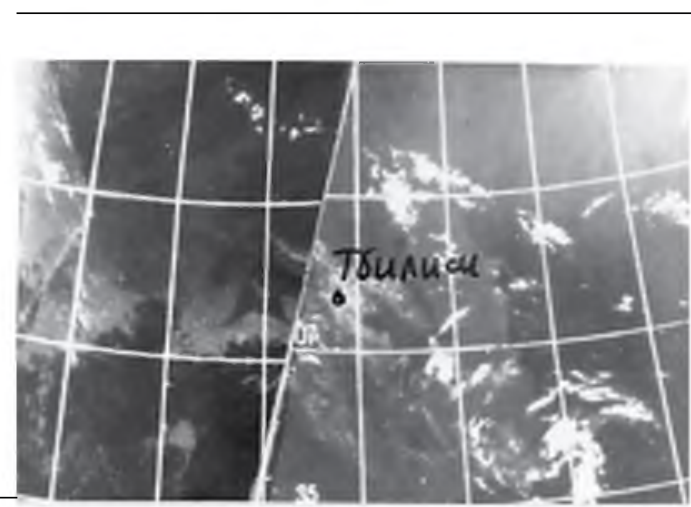

б)

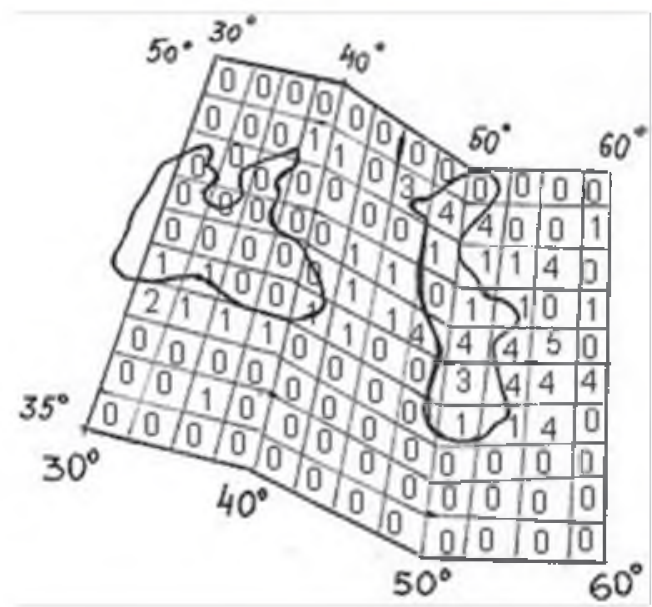

B)

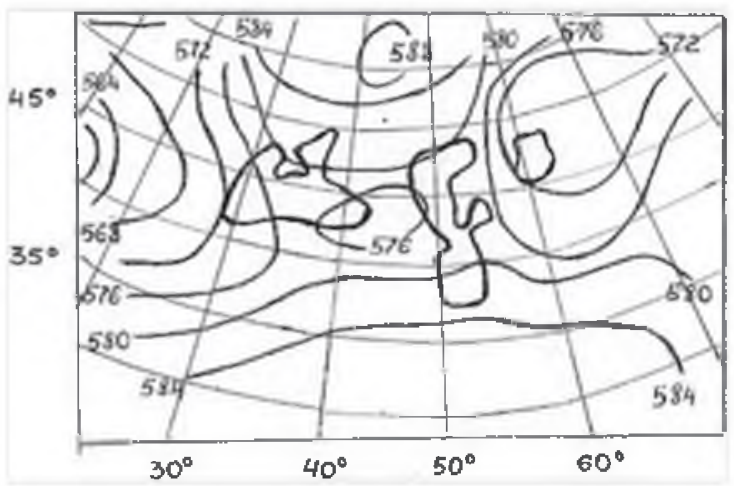

Pис. 11.

Tип VI ( $\left.\mathrm{K}_{28}\right)$. Снимок облачности ИС3 (a), соответствующие численная карта облачности в баллах (б) и синоптическая ситуация на $\mathrm{AT}_{500}$ (B).

Fig. 11. Type $\mathrm{VI}\left(\mathrm{K}_{28}\right)$. The cloudiness image of $A E S(a)$, corresponding numerical map of cloudiness in cloud amounts (b) and synoptical situation at $A T_{500}(c)$. 
a)

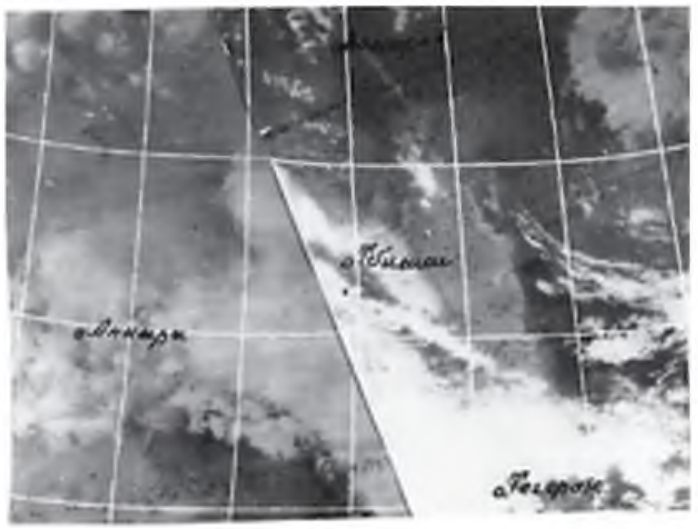

б)

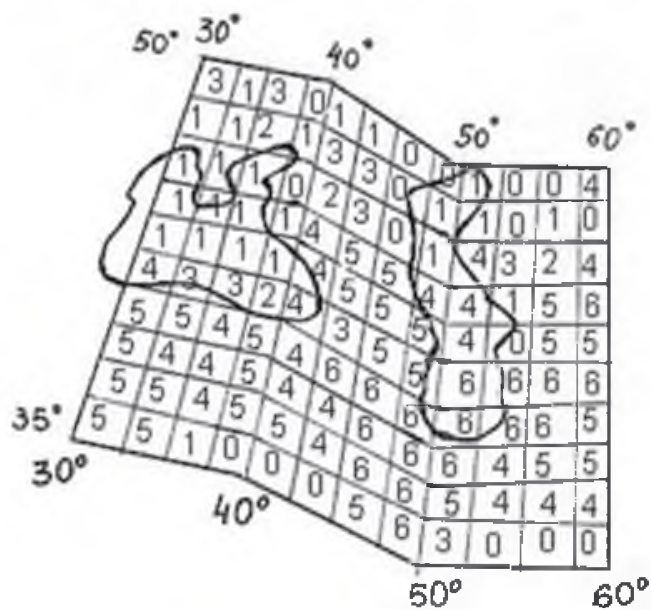

B)

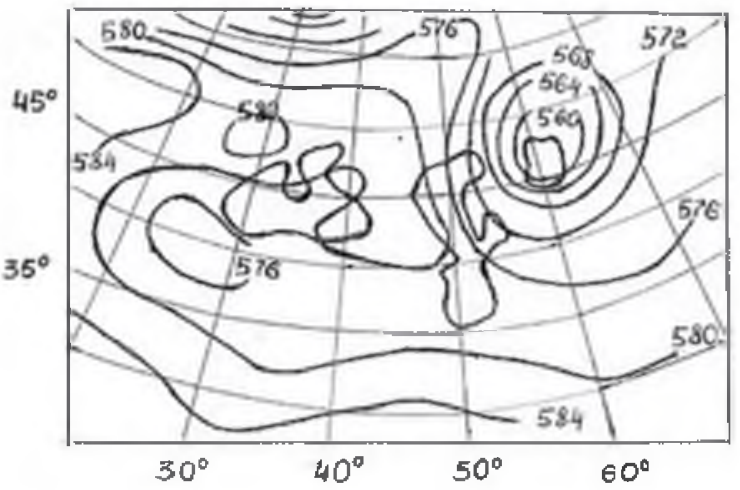

Рис. 12.

Tип VII (K $\mathrm{K}_{69}$ ). Снимок облачности ИС3 (a), соответствующие численная карта облачности в баллах (б) и синоптическая ситуация на $\mathrm{AT}_{500}$ (в).

Fig. 12. Type VII $\left(\mathrm{K}_{69}\right)$. The cloudiness image of AES (a), corresponding numerical map of cloudiness in cloud amounts (b) and synoptical situation at $A T_{500}$ (c). 
a)

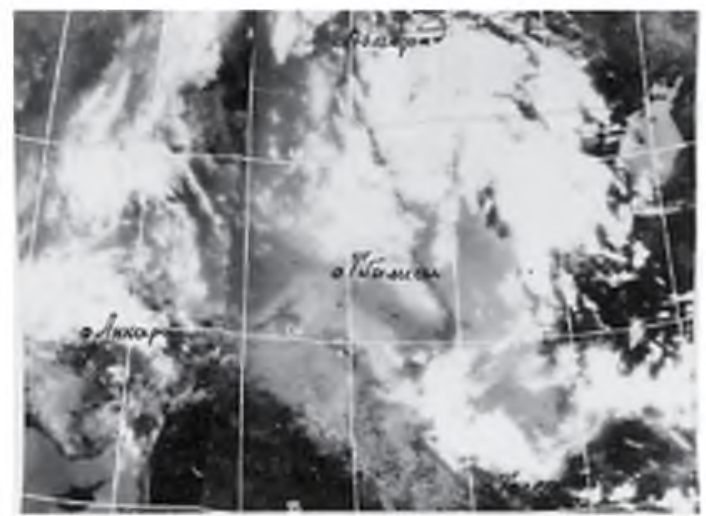

б)

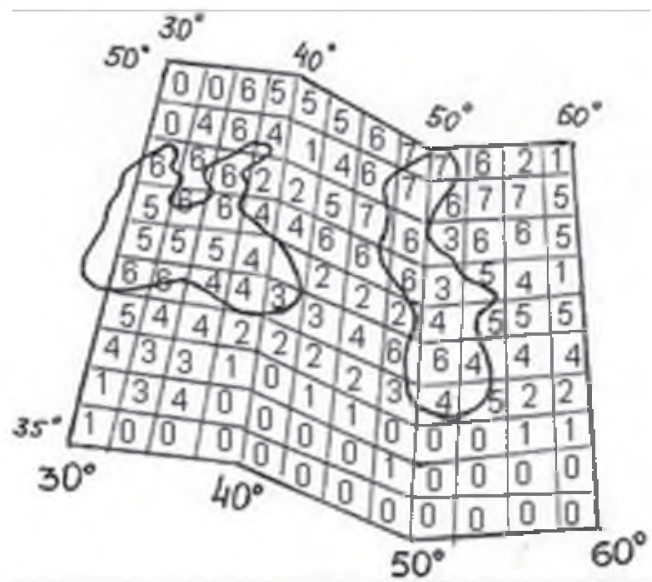

B)

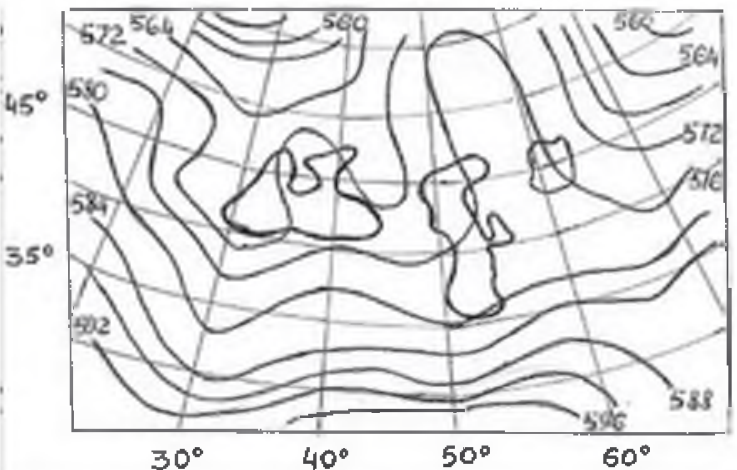

Рис. 13.

Тип VIII (K 24 ). Снимок облачности ИС3 (a), соответствующие численная карта облачности в баллах (б) и синоптическая ситуация на $\mathrm{AT}_{500}$ (B).

Fig. 13. Type VIII $\left(\mathrm{K}_{24}\right)$. The cloudiness image of AES (a), corresponding numerical map of cloudiness in cloud amounts (b) and synoptical situation at $A T_{500}(c)$. 
a)

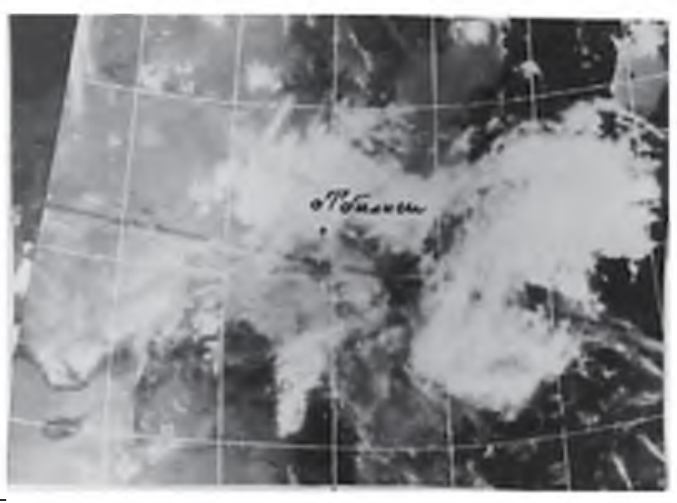

б)

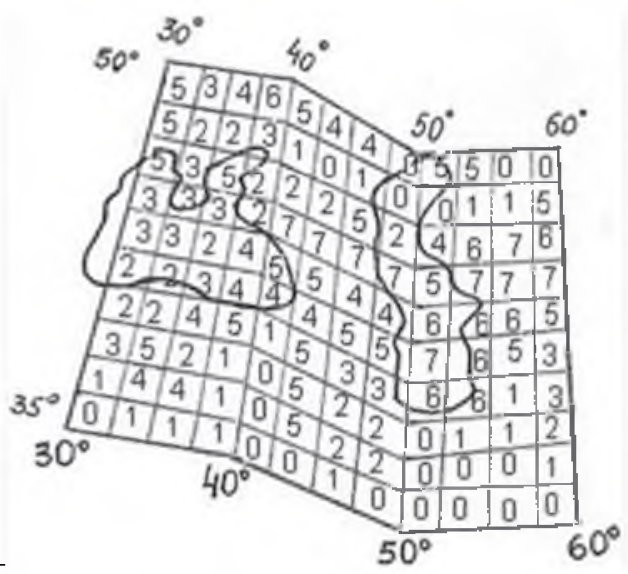

в)

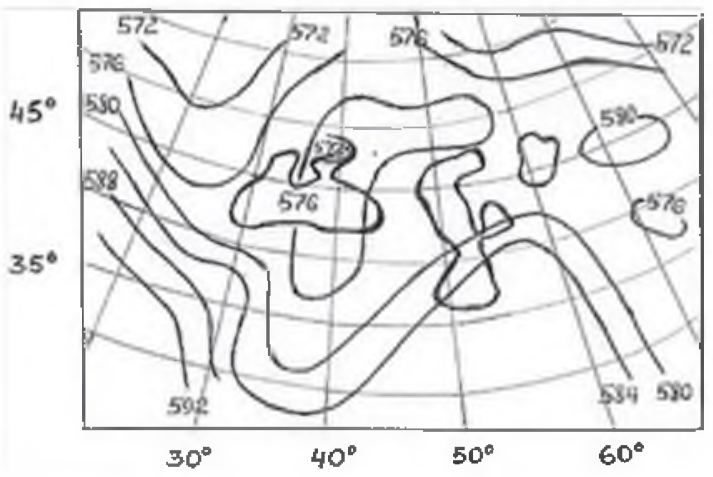

Рис. 14.

Тип IX (K $\left.\mathrm{K}_{63}\right)$. Снимок облачности ИС3 (a), соответствующие численная карта облачности в баллах (б) и синоптическая ситуация на $\mathrm{AT}_{500}$ (в).

Fig. 14. Type IX $\left(K_{63}\right)$. The cloudiness image of AES (a), corresponding numerical map of cloudiness in cloud amounts (b) and synoptical situation at $A T_{500}$ (c). 
Согласно СКП от 05.07.1981 г. IX тип $\left(K_{63}\right)$ характеризуется тем, что:

- синоптические процессы этого типа определяются полем относительно низкого давления, ось которого направлена от центральных районов России в сторону западной Грузии;

- $\quad$ на юго-востоке отмечается поле относительно высокого давления,ось которого направлена от юго-запада на северовосток.

В этом случае вторжение холодных воздушных масс в районах Восточной Грузии наблюдается с севера, а теплых - с юго-запада, что способствует формированию кучево-дождевой облачности, сопровождающейся особо опасными явлениями (ООЯ) погоды (рис. 14). Такой тип соответствует южному типу погоды над Закавказьем.

Анализ рисунков 6-14 позволил рассчитать распределение повторяемостей $(П, \%)$ типов облачности (ТО), включающих в себя [I $\left.\left(K_{17}\right)-\mathrm{IX}\left(K_{63}\right)\right]$, (табл. 3) и типов погоды (ТП), включающих в себя (МПТП-В) в зависимости от направления движения воздушных масс (табл. 3).

ТП, включают в себя: МПТП - малоподвижный тип погоды, С - северный тип погоды, С3 - Северо-западный тип погоды, Ю3 - юго-западный тип погоды, 3 - западный тип погоды, СВ - северо-восточный тип погоды, ЮВ юго-восточный тип погоды и В - восточный тип погоды.

Из таблицы 3 следует, что наибольшую повторяемость (47\%) имеет ТО I $\left(K_{17}\right)$, а наименьшую повторяемости $(1 \%)$ - TO VII $\left(K_{69}\right)$ и TO IX $\left(K_{63}\right)$; повторяемости ПООС, имеющих западную составляющую перемещения $\left(K_{176}+\right.$ $K_{8}+K_{28}$ ) достигают $30 \%$, а имеюших восточную составляющую перемещения $\left(K_{69}+K_{24}+K_{63}\right)-4 \%$

Таблица 3.

РАСПРЕДЕЛЕНИЕ ПОВТОРЯЕМОСТИ (П, \%) ТИПОВ ОБЛАЧНОСТИ (ТО, К) И ТИПОВ ПОГОДЫ (ТП), В ЗАВИСИМОСТИ ОТ НАПРАВЛЕНИЯ ДВИЖЕНИЯ ПОЛЕЙ ОБЛАЧНОСТИ

Table 3. THE DISTRIBUTION OF REPETITION (R, \%) OF TYPES $\left(K_{i}\right)$ AND WEATHER TYPES (WT) DEPENDING ON THE DIRECTION OF CLOUDINESS FIELDS MOVEMENT

\begin{tabular}{llllllllll}
\hline Tип & I & II & III & IV & V & VI & VII & VIII & IX \\
\hline TO $\left(K_{i}\right)$ & $\left(K_{17}\right)$ & $\left(K_{88}\right)$ & $\left(K_{177}\right)$ & $\left(K_{176}\right)$ & $\left(K_{8}\right)$ & $\left(K_{88}\right)$ & $\left(K_{88}\right)$ & $\left(K_{24}\right)$ & $\left(K_{88}\right)$ \\
\hline TП & MПTП & B & C & C-3 & Ю-3 & 3 & C-B & Ю-B & B \\
\hline П (\%) & 47 & 6 & 13 & 21 & 7 & 2 & 1 & 2 & 1 \\
\hline
\end{tabular}



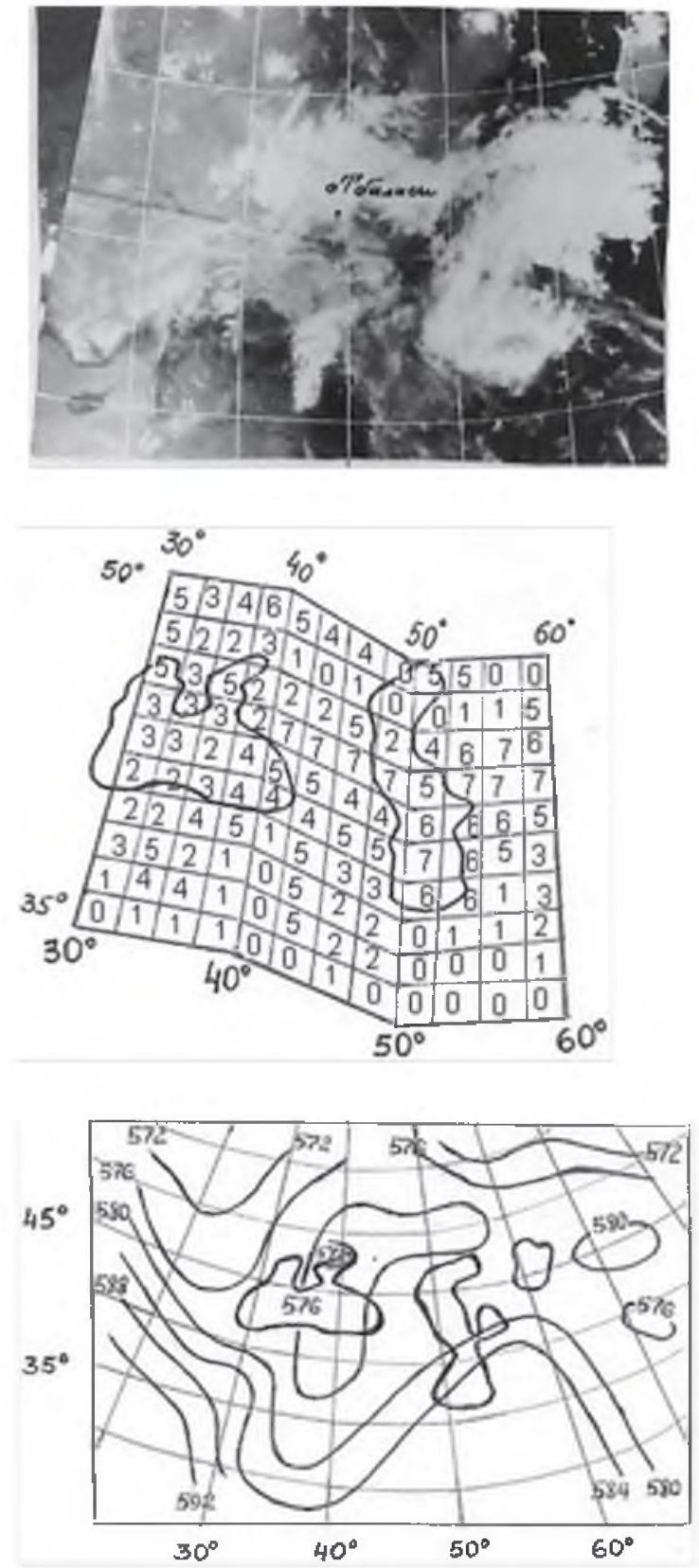

Рис. 14.

Тип IX $\left(\mathrm{K}_{63}\right)$. Снимок облачности ИС3 (a), соответствующие численная карта облачности в баллах (б) и синоптическая ситуация на $\mathrm{AT}_{500}$ (в).

Fig. 14. Type $I X\left(K_{63}\right)$. The cloudiness image of $A E S(a)$, corresponding numerical map of cloudiness in cloud amounts (b) and synoptical situation at $A T_{500}$ (c). 


\section{Выводы}

В регионе Центрального Кавказа и прилегающих территорий усовершенствован метод классификации ПООС, который лег в основу районирования ПООС и классификации синоптических процессов.

При районировании рассчитаны вероятности формирования общей облачности и облачности различных типов (баллов), построены карты вероятности формирования общей облачности с шагом $20 \%$ и отдельных типов облачности с шагом $10 \%$, выявлены районы их интенсивного развития, оценен вклад отдельных типов облачности в общую.

Максимум вероятности формирования незначительной облачности (01 балл) расположен южнее Закавказья, небольшой облачности (2-3 балла) перемешается в южных районах Закавказья, значительной облачности (4-5 баллов) отмечается по всей территории Кавказа и прилегающих территории, самых интенсивных процессов (6-7 баллов) расположен на южных и северных склонах Большого Кавказского хребта.

Наибольшей интенсивности развитие облачности достигает не в очагах их зарождения, а над Центральным Кавказом. Причиной является не масштаб синоптических процессов, а физико-географические особенности подстилаюшей поверхности исследуемого региона.

Усовершенствован полу автоматизированный метод классификации синоптических процессов, учитывающий направление перемещения ПООС и интенсивность протекающих в них грозоградовых процессов, сопровождающихся осадками и шквалами различной силы.

Выявлены 9 классов синоптических ситуаций и рассчитаны их повторяемости.

Полученные результаты могут быть привлечены:

для совершенствования методов диагноза и прогноза опасных явлений погоды, сопровождающихся слабыми, умеренными и сильными осадками, грозоградовыми процессами и шквалами различной силы;

при планировании, организации и проведении работ по воздействию на градовые процессы и искусственному увеличению осадков в различных районах исследуемой территории;

в оценках физической и экономической эффективности явлений погоды, противоградовых работ и работ по искусственному увеличению осадков. 


\section{Библиографический список}

1. Абшаев М.Т., Абшаев А.М., Малкарова А.М., Барекова М.В. Руководство по организации и проведению противоградовых работ. Нальчик: Печатный двор, 2014. 500 с.

2. Бартишвили Я.Т., Надибаидзе ГА. Бегалишвили Н.А., ГудушауриШ.Л. К ффизическим основам метода ЗакНИГМИ борьбы с градом // Труды ЗакНИГМИ. 1978. Вып. 67(73). С. 7382.

3. Бочарников Н.В., Брылев Г.Б., Песков Б.Е., Ватиашвили М.Р., Хохлов Г.В. Методические указания по определению шквалов с использованием данных МРЛ. Л.: Гидрометеоиздат, 1988. 23 с.

4. Ватьян М.Р., Ломидзе Н.Э. Исследование ресурсов поля облачности по данным ИСЗ // Тр. Всесоюзной конференции по активным воздействиям на гидрометеорологические процессы. Киев, 1990. С. 89-93.

5. Ватиашвили М.Р, Шенгелия Л.Д. Методы районирования полей облачности и осадков и получения вероятностных карт их распределения по данным снимков ИСЗ. Информационное письмо Грузинского республиканского управления по гидрометеорологии. Тбилиси, 1993. №2 (133). С. 43-51.

6. Ватиашвили М.Р, Шенгелия Л. Д. Классификация и краткосрочный прогноз полей облачности и осадков над территорией Кавказа с использованием данных ИСЗ // Труды института гидрометеорологии АН Грузии, 1996, т. 100. С. 59-66.

7. Ватиашвили М.Р. Метод прерывания града на подступах защищаемой территории со стороны вторжения градовых облаков // Наука. Инновации. Тех-нологии. 2016. №4. С. 7-24.

8. Ватиашвили М.P. Состояние полей облачных систем и опасных явлений погоды, развивающихся в регионе Центрального Кавказа // Наука. Инновации. Технологии. 2019. №1. С. 91-116.

9. Ватиашвили М.Р. Метод прерывания града на защищаемых территориях региона Центрального Кавказа // Наука. Инновации. Технологии. 2018. №1. С. 7-22.

10. Ватиашвили М.Р Обзор методов противоградовой защиты в регионе Центрального Кавказа // Наука. Инновации. Технологии. 2018. №3. С. 48-65.

11. Гигинейшвили В.М., Напетварицзе Е.А. Папинашвили К.Н. Основные типы синоптических процессов в Закавказье. Труды ТбилНИГМИ, 1954. Вып. 1, Л.: Метеоиздат. С. 3-21.

12. Глушкова Н.И. Прогноз осадков по данным спутниковых и радиолокационных наблюдений // Тр. Гидрометцентра СССР. 1985. Вып. 266. С. 21-23.

13. Зверев А.С. Синоптическая метеорология и основы пред вычисления погоды. Л.: Гидрометеоиздат, 1968. 711 с.

14. Карцивадзе А.И., Салуквадзе Т.Г., Лапинскас В.А. Некоторые вопросы методики воздействия на градовые процессы с ис- 
пользованием противоградовой системы «Алазань» // Труды института геофизики АН Грузии. 1975. Т. 26. С. 13-27.

15. Коган Р.Л. Осреднение метеорологических полей Л., Гидрометеоиздат, 1979. 212 C.

16. Мазин И.П. О классификации облаков по их фазовому строению. Индекс фазового строения облаков // Метеорология и гидрология. 2001. №11. С. 5-17.

17. Матвеев Л.Т. Общая метеорология. Физика атмосферы. Л.: Гидрометеоиздат, $1976.639 \mathrm{c}$

18. Николаев Ю.В. Преобразование информации в применении к задачам гидрометеорологии. Гидрометеоиздат, 1969, 64 с.

19. Облака и облачная атмосфера. Справочник / под ред. И.П. Мазина и А.Х. Хргиана, Л.: Гидрометеоиздат, 1989. 647 с.

20. Папинашвили К.И. Атмосферные процессы в Закавказье и их связь с микро-циркуляционными процессами над Евразией. Л.: Гидрометеоиздат, 1963. $184 \mathrm{c}$.

21. Руководство по использованию спутниковых данных в анализе и прогнозе погоды. Л., Гидрометеоиздат, 1982. 199 с.

22. Сванидзе Г.Г., Бегалишвили Н.А., Ватьян М.Р., Карцивадзе А.И., Гудушаури Ш.Л. Методические указания по организации и проведению работ по искусственному увеличению осадков из конвективных облаков с помощью противоградовой техники. М.: Гидрометеоиздат, 1986. 25 с.

23. Сулаквелидзе Г.К. Ливневые осадки и град. Л.: Гидрометеоиздат, 1967. 421c.

24. Физика облаков / под ред. А.Х. Хргиана и др. Л.: Гидрометеоиздат, 1969. 647 c.

25. Хргиан А.Х., Новожилова Н.И. Атлас облаков. Л.: Гидрометеоиздат,

26. Чернова В.Ф. Прогноз эволюции и направления перемещения облачных систем с заблаговременностью 24 ч по спутниковым изображениям. Информационный сборник. №9. 1981. С. 51-56.

27. Шенгелия Л.Д. Способ объективной классификации метеорологических полей с минимальным числом классов. Труды Гидрометцентра СССР, 1979. Вып. 216, С. 120-131.

28. Шенгелия Л.Д. Методика прогноза поля облачности над Закавказьем с заблаговременностью 12 и 24 часа по данным спутниковой информации. Информационное письмо Грузинского республиканского управления по гидрометеорологии. Тбилиси, 1987. №4 (120). С. 10-18.

29. Шенгелия Л.Д. Анализ изображений облачных систем по данным спутниковой информации над Закавказьем и прилегающей территорией. Информационное письмо Грузинского республиканского управления по гидрометеорологии. Тбилиси 1988, №2 (122). C. 23-25.

30. Экба Я.А., Свириденко А.С. Работы по искусственному увеличению осадков на Северном Кавказе. Труды СФ ВГИ, 199, вып. 1. C. $3-8$. 


\section{References}

1. Abshaev M.T., Abshaev A.M., Malkarova A.M., Barekova M.V. Rukovodstvo po organizatsii i provedeniyu protivogradovykh rabot (The Manual on organizing and executing of anti-hail works). NaIchik, 2014: Pechatnyi dvor. $500 \mathrm{~s}$.

2. Bartishvili Ya.T., Nadibaidze G.A. Begalishvili N.A., Gudushauri Sh.L. K fizicheskim osnovam metoda ZakNIGMI bor'by s gradom (To the physical foundations of ZakNIGMI method of hail control) // Trudy ZakNIGMI. 1978. Vyp. 67(73). S. 73-82.

3. Bocharnikov N.V., Brylev G.B., Peskov B.E., Vatiashvili M.R., Khokhlov G.V. Metodicheskie ukazaniya po opredeleniyu shkvalov $s$ ispol'zovaniem dannykh MRL. (The study guide on squal determining using MRL data) L.: Gidrometeoizdat, 1988. $23 \mathrm{~s}$.

4. Vat'yan M.R., Lomidze N.E. Issledovanie resursov polya oblachnosti po dannym ISZ (The research of cloudiness field using ISZ data) // Tr. Vsesoyuznoi konferentsii po aktivnym vozdeistviyam na gidrometeorologicheskie protsessy. Kiev, 1990. S. 89-93.

5. Vatiashvili M.R., Shengeliya L.D. Metody raionirovaniya polei oblachnosti i osadkov i polucheniya veroyatnostnykh kart ikh raspredeleniya po dannym snimkov ISZ. (The methods of geographical demarcation of cloudiness fields and precipitations and obtaining the probability maps of their distribution according to the data of AES images) Informatsionnoe pis'mo Gruzinskogo respublikanskogo upravleniya po gidrometeorologii. Tbilisi 1993. №2 (133). S. 43-51.

6. Vatiashvili M.R, Shengeliya L. D. Klassifikatsiya i kratkosrochnyi prognoz polei oblachnosti i osadkov nad territoriei Kavkaza $\mathrm{s}$ ispol'zovaniem dannykh ISZ (The classification and short-run forecast of the fields of cloudiness and precipitations over the territory of the Caucasus using the AES data) // Trudy instituta gidrometeorologii AN Gruzii, 1996, tom 100. S. 59-66.

7. Vatiashvili M. R. Metod preryvaniya grada na podstupakh zashchishchaemoi territorii so storony vtorzheniya gradovykh oblakov (The method of hail breaking next to the protected area from the direction of hail clouds intrusion) // Nauka. Innovatsii. Tekhnologii. 2016. №4. S. $7-24$

8. Vatiashvili M.R. Sostoyanie polei oblachnykh sistem i opasnykh yavlenii pogody, razvivayushchikhsya $v$ regione Tsentral'nogo Kavkaza (The condition of cloud systems fields and dangerous weather phenomena developing in the region of the Central Caucasus) // Nauka. Innovatsii. Tekhnologii. 2019. №1. S. 91-116.

9. Vatiashvili M.R. Metod preryvaniya grada na zashchishchaemykh territoriyakh regiona Tsentralnogo Kavkaza (The method of hail breaking on the protected areas of the Central Caucasus region) // Nauka. Innovatsii. Tekhnologii. 2018. №1. S. 7-22.

10. Vatiashvili M.R. Obzor metodov protivogradovoi zashchity $v$ regione Tsentral'nogo Kavkaza (The review of methods of anti-hail protec- 
tion in the region of the Central Caucasus) // Nauka. Innovatsii. Tekhnologii. 2018. №3. S. 48-65.

11. Gigineishvili V.M., Napetvaritsze E.A. Papinashvili K.N. Osnovnye tipy sinopticheskikh protsessov $\vee$ Zakavkaz'e.(The main types of synoptic processes in Transcaucasia) Trudy Tbil NIGMI, 1954, vyp. 1, L., Meteoizdat. S. 3-21.

12. Glushkova N.I. Prognoz osadkov po dannym sputnikovykh i radiolokatsionnykh nablyudenii (The forecast of precipitations according to the data of satellite and radar observations) // Tr. Gidromettsentra SSSR. 1985. Vyp. 266. S. 21-23.

13. Zverev A.S. Sinopticheskaya meteorologiya i osnovy pred vychisleniya pogody. (The synoptic meteorology and foundations of weather precomputations). L.: Gidrometeoizdat, 1968. $711 \mathrm{~s}$

14. Kartsivadze A.I., Salukvadze T.G., Lapinskas V.A. Nekotorye voprosy metodiki vozdeistviya na gradovye protsessy s ispolzovaniem protivogradovoi sistemy «Alazani» (Some issues of method of affecting hail processes with anti-hail system «Alazani») // Trudy instituta geofiziki AN Gruzii. 1975. Is. 26. P. 13-27.

15. Kogan R.L. Osrednenie meteorologicheskikh polei (Averaging of meteorological fields). L.: Gidrometeoizdat, 1979. 212 s.

16. Mazin I.P. O klassifikatsii oblakov po ikh fazovomy stroeniyu. Indeks fazovogo stroeniya oblakov (About clouds classification on their phase composition. The index of clouds phase composition) // Meteorology and Hydrology. 2001. №11. P. 5-11.

17. Matveev L.T. Obshchaya meteorologiya. Fizika atmosfery. (General Meteorology. Aerophysics). L.: Gidrometeoizdat, 1976. 639 p.

18. Nikolaev Yu.V. Preobrazovanie informatsii $v$ primenenii k zadacham gidrometeorologii (The information transformation when applying to hydrometeorology tasks). Gidrometeoizdat, 1969. $64 \mathrm{~s}$.

19. Oblaka i oblachnaya atmosfera. Spravochnik (Clouds and cloud atmosphere. Reference book) / pod red. I.P. Mazina and A. Kh. Khgiana. L.: Gidrometeoizdat, 1989. 647 p.

20. Papinashvili K.I. Atmosfernye protsessy $\vee$ Zakavkaz'e i ikh svyaz' s mikro-tsirkulyatsionnymi protsessami nad Evraziei (The atmospheric processes in Transcaucasia and their connection with microcirculation processes over Eurasia: L.: Gidrometeoizdat, 1963. $184 \mathrm{~s}$.

21. Rukovodstvo po ispol'zovaniyu sputnikovykh dannykh $v$ analize i prognoze pogody (The manual on utilizing satellite data in weather analysis and forecast). L., Gidrometeoizdat, 1982. $199 \mathrm{~s}$.

22. Svanidze G.G., Begalishvili N.A., Vatian M.R., Kartsivadze A.I., Gudushauri Sh.L. Metodicheskie ukazaniya po organizatsii i provedeniyu rabot po iskusstvennomu uvelicheniyu osadkov iz konvektivnykh oblakov s pomosh'yu protigradovoy tekhniki. (The study guide on arranging and carrying out activities on artificial increasing of weather precipitations from convective clouds by means of antihail equipment) // M.: Gidrometeoizdat, 1986. 25 p.

23. Sulakvelidze G.K. / Livnevye osadki i grad (Cloud bursts and hailing). L.: Gidrometeoizdat, 1967, $421 \mathrm{p}$ 
24. Fizika oblakov (The Physics of clouds) / Pod. Red. A. Kh. Khrgiana i dr. L.: Gidrometeoizdat, 1969. 647 p.

25. Khrgian A. Kh., Novozhilova N. I. Atlas oblakov (The Clouds Atlas) L.: Gidrometeoizdat, 1978. 268 p.

26. Chernova V.F. Prognoz evolyutsii i napravleniya peremeshcheniya oblachnykh sistem s zablagovremennost'yu 24ch po sputnikovym izobrazheniyam (The forecast of evolution and direction of cloud systems dislocation prior to 24 hours on satellite images). Informatsionnyi sbornik. №9. 1981. S. 51-56.

27. Shengeliya L.D. Sposob ob»ektivnoi klassifikatsii meteorologicheskikh polei s minimal'nym chislom klassov (The method of the objective classification of meteorological fields with the minimum number of classes). Trudy Gidromettsentra SSSR, 1979, vyp. 216. S. $120-131$.

28. Shengeliya L.D. Metodika prognoza polya oblachnosti nad Zakavkaz'em s zablagovremennost'yu 12 i 24 chasa po dannym sputnikovoi informatsii (The technique of forecast of cloudiness field over Transcaucasia prior to 12 and 24 hours according to satellite data). Informatsionnoe pis'mo Gruzinskogo respublikanskogo upravleniya po gidrometeorologii. Tbilisi 1987. №4 (120). S. 10-18.

29. Shengeliya L.D. Analiz izobrazhenii oblachnykh sistem po dannym sputnikovoi informatsii nad Zakavkaz'em i prilegayushchei territoriei (The analysis of cloud systems images on the satellite data over Transcaucasia and adjacent territory). Informatsionnoe pis'mo Gruzinskogo respublikanskogo upravleniya po gidrometeorologii. Tbilisi 1988. №2 (122). S. 23-25.

30. Ekba Ya. A., Sviridenko A.S. Raboty po iskusstvennomu uvelicheniyu osadkov na Severnom Kavkaze (The works on artificial precipitations inscreasing in the North Caucasus). Trudy SF VGI, 199, vyp. 1. S. 3-8.

\section{Поступило в редакцию 27.10.2019, принята к публикации 02.12.2019}

\section{O6 авторах}

Ватиашвили Михаил Рубенович, кандидат географрических наук, доцент, Грузинский государственный научно-технический центр «Дельта» министерства обороны Грузии. Грузия, г. Тбилиси. Научный консультант по проектам. Телефон: + 995 598-341451. E-mail: Mivv123@mail.ru

\section{About the author}

Vatiashvili Mikhail Rubenovich, Candidate of geographical sciences The senior lecturer Georgian state scientific and technological center «Delta» Ministries of Defence of Georgia Scientific consultant for projects. Phone: +995 598-341-451. E-mail: Mivv123@mail.ru. 